\title{
Karma yem üretiminde müşteri ihtiyaçlarının karşılanmasına yönelik kalite fonksiyonu göçerimi uygulamasi
}

\author{
Özlem KUVAT ${ }^{1, *}$, Gülşah ABATAY ${ }^{2}$ \\ ${ }^{1}$ Balıkesir Üniversitesi İ̈BF. İşletme. Böl., Çă̆lş kampüsü, Balıkesir \\ ${ }^{2}$ Makrolab Zem. Ar. Ve Yap. Malz. Lab Inş. Taah. San. ve Tic. Ltd. Şti, Yenişehir, Mersin \\ Geliş Tarihi (Received Date): 17.01.2020 \\ Kabul Tarihi (Accepted Date): 24.04.2020
}

$\ddot{\mathbf{O z}}$

Yüksek miktarda ve nitelikli hayvansal besinlerin elde edilebilmesi için bu hayvanların beslenmesinde kullanılan yemlerin gerekli özellikleri taşıması büyük önem taşımaktadır. Bu nedenle bu çalışmada yem üretiminde müşterinin sesinin dikkate alınmasıyla müşteri memnuniyetini arttırmak, yaşanan sorunlara ve aksaklıklara çözüm üretebilmek hedeflenmiştir. Bu çalışmada, Balıkesir ilinde üretim yapmakta olan bir yem fabrikası için hayvan yetiştiren işletmelerin gereksinim ve şikayetlerini saptamak ve süreci iyileştirmek adına Kalite Fonksiyonu Göçerimi uygulanmıştır. Müşteriler bu ilde hayvancılık sektöründe faaliyet gösteren hayvancllı işletmeleri yöneticileridir. Araştırmaya ait analizler, Ocak- Nisan 2019 tarihleri arasinda elde edilen veriler üzerinden yapılmıştır. Gemba analizi ile müşteri istekleri yerinde incelenmiş ve müşteri beklentileri doğrudan gözlemler sonucunda toplanmıştır. Yem üretimi için kalite, fiyat, paket/ ambalaj, dağıtım olarak gruplanan müşteri ihtiyaçlarının önem düzeyleri hesaplanarak isteklere karşılık gelebilecek teknik karakteristikler belirlenmiştir. Müşteri ihtiyaçları ile bunları karşılayabilecek teknik karakteristikler arasındaki ilişkinin incelenmesi, teknik önem seviyesinin belirlenmesi, rekabet analizi aşamalarından sonra kalite evi oluşturulmuştur. Müşteri beklentisi kısmı için en önemli kriter "Teslimatın Zamanında Gerçekleşmesi" iken karşılık gelen teknik karakteristikler içinde "Ödeme Şekli Fiyat İndirimi" en yüksek değeri almıştır.

Anahtar kelimeler: Kalite fonksiyonu göçerimi, kalite evi, gemba analizi, karma yem.

\footnotetext{
* Özlem KUVAT, ohasgul@ balikesir.edu.tr, http://orcid.org/0000-0001-7017-4557

Gülşah ABATAY, gulsah_abatay@hotmail.com,_http://orcid.org/0000-0003-2011-7233
} 


\title{
Application of quality function deployment to meet customer requirements in compound feed production
}

\begin{abstract}
In order to obtain high quantity and qualified animal foods, it is of great importance that the feeds used in feeding these animals have the necessary characteristics. For this reason, in this study, it is aimed to increase customer satisfaction by considering voice of customer in feed production and to produce solutions to problems and problems. In this study, Quality Function Deployment has been applied in order to improve the process and identify needs and complaints of animal breeding enterprises for a feed factory which is producing in Ballkesir province. Customers are the managers of livestock enterprises operating in the livestock sector in this province.The analyzes of the research were made on the data obtained between January and April 2019. The customer requests were analyzed on site by means of gemba analysis and the expectations were collected directly from the observations. Technical characteristics that can correspond to the demands were determined by calculating the importance levels of customer needs grouped as quality, price, packaging, distribution for feed production. After examining the relationship between customer needs and the technical characteristics that can meet them, determining the level of technical importance, and the competitive analysis stages, the quality house was created. While the most important criterion for the customer expectation part is "Delivery on Time", "Payment Type Price Discount" has received the highest value among the corresponding technical characteristics.
\end{abstract}

Keywords: Quality function deployment, house of quality, gemba analysis, compound feed.

\section{Giriş}

Dünyada gıda üretimi ve ihtiyacı dikkate alındığında gıdaya erişimin zamanla zorlaştığı görülmektedir. Buna yol açan başlıca faktörler; gelir değişimi, nüfus artışı, iklim değişikliği ve kuraklık, su kaynaklarındaki azalma, şehirleşmenin artışı, tarıma elverişli topraklardaki daralma ve bazı tahılların biyoyakıt olarak kullanımı gibi faktörlerdir. $\mathrm{Bu}$ durum insan beslenmesinde çok büyük bir öneme sahip olan tarım-gıda sektörünü ve hayvancılıktaki gelişmeleri de etkilemektedir. Hayvancılık ve yem sektörleri değerlendirildiğinde FAO, WHO, OECD, IFIF gibi küresel kurumların da bu sıkıntılara ilişkin ve sürdürülebilirlik, gıda güvenliği, eşitlik/büyüme, aile tipi hayvancılık konularına dikkat çektiği görülmektedir [1].

Hayvancılığın gelişim düzeyi, hayvancılığa girdi sağlayan sanayinin gelişimine bağlıdır. Hayvancılığın gelişmesinde en büyük unsurlardan biri önemli besin kaynaklarından olan yemdir. Bu nedenle yem sanayisi de özellikle endüstriyel hayvancıllk için önem kazanmaktadır. Yem sanayisinde oluşabilecek herhangi bir olumsuzluk ve sorun, hayvansal üretim üzerinde ciddi bir etkiye yol açabilecektir [2].

Hayvanların günlük besin gereksinimini karşılayabilmek ve hayvansal ürün üretimi ile verimini artırmak için birden fazla yemin karıştırılmasıyla karma yem elde edilmektedir. 
Hayvancılık işletmelerinin en büyük gideri yem giderleridir. Yem giderleri, hayvancılık sektöründe işletme giderlerinin yaklaşık \% 70'ni oluşturmaktadır [3]. Bu nedenle önemi gün geçtikçe artan tarım gıda ve karma yem sektöründe müşteri gereksinimlerine karşılık gelebilecek kalitede ürünlerin üretimi işletmeler için ana problemlerden birisini oluşturmaktadır. Düşük maliyet ile üretim kaynaklarını en verimli şekilde kullanmak ve rekabet üstünlüğü elde etmek için müşteri gereksinimlerini ve isteklerini doğru anlamak gerekmektedir [4].

Tarım-gıda ve yem sektörü için rekabet koşulları altında iyileştirme sağlanabilmesi ve müşteri memnuniyetinin artırılması adına müşteri gereksinimlerinin doğru belirlenmesi, gereksinimlerin ve isteklerin önem seviyelerinin derecelendirilmesi sonucunda kalite evine uygun yerleşimle bu gereksinimlerin nasıl karşılanacağının incelenmesi yaşanan problemlerin çözümünde sistematik bir yol sağlayacaktır.

Bu çalışmada, Balıkesir'de bulunan bir karma yem işletmesinin tüm süreçleri incelenmiş ve müşteri beklentileri ile işletmenin beklentilerine uygun teknik karakteristikler üzerinde durulmuştur. Çalışmada müşteri istekleri bilincini temel alan sistematik bir yaklaşım olması nedeniyle literatürde yer alan çalışmalardan farklı olarak yem üretimi için kalite, fiyat, paket/ ambalaj, dağıtım gibi alanları birlikte değerlendirecek biçimde bir uygulama geliştirilmiştir.

Çalışma beş bölümden meydana gelmektedir. Çalışmanın ikinci bölümünde karma yem sektörü ve gelişimi açıklanarak sektörün durumu özetlenmeye çalışılmıştır. Buna ek olarak karma yem sektörü ile ilgili yapılan bir literatür araştırması sunulmuştur. Kalite Fonksiyonu Göçerimi yöntemi tanıtımı çalışmanın üçüncü bölümünde yer almıştır. Çalışmanın dördüncü bölümünü ise Kalite Fonksiyonu Göçeriminin yem fabrikasında uygulama aşamalarına yer verilmiştir. Son bölümünde sonuçlar verilmiş ve değerlendirmeler yapılmıştır.

\section{Karma yem işletmeleri}

Yemler, hayvanlara yedirildiğinde, sağlıklarına herhangi bir zararlı etkisi olmayan ve onların faydalanabilecekleri bir şekilde organik veya inorganik besin maddelerini içeren materyallerdir. Fabrika yemi olarak adlandırılan karma yem ise; enerjili yem, \%20 ve daha fazla proteinli yem, mineral ile vitamin katkı maddeleri karışımından oluşan besinlerdir. Bir karma yem karışımına 50 civarında madde karışabilmektedir. Yem fabrikaları ise; çeşitli hayvanların verim ve yağ durumları dikkate alınmak suretiyle en düşük maliyetli ve en verimli olacak şekilde hazırlanan karma yem formüllerinin (rasyon) kullanıldığ 1 tesislerdir [5].

2018 y1lı verilerine göre; Dünya karma yem üretiminin \%42'sini kanatlı yemleri, \%19'unu ruminant (geviş getiren) yemleri oluşturmaktadır. İlk sırada 188 milyon ton üretim ile Çin bulunmaktadır. İkinci ve üçüncü sırada 177 milyon ton ile ABD ve Brezilya yer almaktadır. Türkiye ise; kendi yemini üretenler de dahil Dünyada yedinci sıradadır ve AB ülkeleri arasında ilk sırada bulunmaktadır [6]. Türkiye Cumhuriyeti, Tarım ve Orman Bakanlığı Gıda ve Kontrol Genel Müdürlüğü'nün Temmuz 2019'da yayınladığı rakamlara göre, Karma Yem Üreten İşletme sayısı 671'dir. 13.317'si perakende yem depolama ve satış yeri olmak üzere yem sektöründe olan toplam 15.036 işletme bulunmaktadir [7]. 
Karma yem üretim gruplarının yıllara göre dağılımı Tablo 1'de gösterilmektedir. 2018 yılında toplam 24.144.489 ton karma yem üretilmiş olup bunun 5.072.549 tonunu sığır besi yemi, 6.481.999 tonunu sığır süt yemi, 5.306.118 tonunu etlik piliç yemi, 3.600.843 tonunu yumurta yemi ve 3.682.980 tonunu diğer karma yemler oluşturmaktadır. Türkiye'de son 5 yılda yem üretiminde sürekli artış sağlanmıştır. 2019 Temmuz ayı verilerine göre ise, toplamda 11.107.700 ton karma yem üretilmiştir. Burada diğer karma yemler küçükbaş yemleri, at yemi, balık yemleri, ev ve süs hayvanları yemleri, arı keki vb. yemlere karş1lık gelmektedir. [7].

Tablo 1. Balıkesir'de karma yem gruplarının 2013-2019 yıllarına göre üretim miktarları (ton).

\begin{tabular}{|c|c|c|c|c|c|c|}
\hline Y11 & $\begin{array}{c}\text { Siğır Besi } \\
\text { Yemi }\end{array}$ & $\begin{array}{c}\text { Siğır Süt } \\
\text { Yemi }\end{array}$ & $\begin{array}{c}\text { Etlik Piliç } \\
\text { Yemi }\end{array}$ & $\begin{array}{c}\text { Yumurta } \\
\text { Yemi }\end{array}$ & $\begin{array}{c}\text { Diğer } \\
\text { Karma } \\
\text { Yemler }\end{array}$ & $\begin{array}{c}\text { Genel } \\
\text { Toplam }\end{array}$ \\
\hline 2013 & 2.846 .217 & 5.163 .788 & 4.083 .687 & 1.602 .364 & 2.265 .811 & 15.961 .867 \\
\hline 2014 & 3.386 .565 & 5.621 .664 & 3.979 .945 & 2.480 .547 & 2.534 .895 & 18.003 .616 \\
\hline 2015 & 3.320 .221 & 5.384 .586 & 4.779 .916 & 3.417 .209 & 3.203 .051 & 20.104 .983 \\
\hline 2016 & 3.827 .073 & 5.840 .262 & 4.566 .237 & 2.958 .232 & 3.210 .048 & 20.401 .852 \\
\hline 2017 & 4.594 .552 & 6.171 .275 & 4.753 .989 & 3.369 .655 & 3.528 .862 & 22.418 .333 \\
\hline 2018 & 5.072 .549 & 6.481 .999 & 5.306 .118 & 3.600 .843 & 3.682 .980 & 24.144 .489 \\
\hline $\begin{array}{c}2019 \\
\text { Temmuz }\end{array}$ & 2.450 .206 & 2.937 .951 & 2.447 .356 & 1.692 .910 & 1.579 .378 & 11.107 .700 \\
\hline
\end{tabular}

Yem sektörüne ilişkin bu değerler sektörün önemini etkili bir şekilde vurgulamaktadır. Karma yem sektörü ile ilgili çok sayıda çalışma bulunmaktadır. Yapılan çalışmaların büyük bölümü karma yem işletmelerinin sorunları üzerine ya da rasyon ve maliyet optimizasyonu üzerine gerçekleştirilmişlerdir.

Buxton (1996) [8], çalışmasında bitkilerin yetiştiği ortamından ve tarımsal faktörlerden etkilenen yemlerin kaliteye bağlı özelliklerini değerlendirmiştir. Gelişmiş yem kalitesi ile yeni çeşitler üretme potansiyeline değinmiştir. Basmacioğlu (2004) [9], karma yem üretiminde pelet kalitesine etki eden etmenleri incelemiş; bunun için dayanıklılık, sertlik, uzunluk, tozluluk değeri, renk, dış yüzey görünümü, lezzet kriterlerini değerlendirmiştir. Berkum (2005) [10], çalışmasında AB katılımı için Türk tarım-gıda zinciri, çiftlik ve gıda sektörünün modernizasyonu ile yeniden yapılandırılması ve daha verimli pazarlama gerektiren çalışmalar konusunda öneriler sunmaktadır. Anıç ise (2006) [11], Trakya Bölgesinde bulunan yem üretim işletmelerinin hammadde bulmada ve yemi pazara sunmada yaşadıkları sıkıntıları ele almıştır. Çalışmada bölgede bulunan 27 adet karma yem işletmesi ile görüşülerek yaşanan sıkıntılar belirlenmeye çalışılmış SWOT analizi yapılmıştır. Meuwissen vd. (2008) [12], çalışmalarında Hollanda'daki ıslak yem üzerine tarım-gıda tedarik zincirlerinde sorumluluk risklerini değerlendirmişlerdir. Hasar olarak düşünülen bileşenler; hayvanların itlaflanması, büyüme bozulması ve kalitesinin düşmesi ile toplanmayan süt konusundadır. Şahman (2008) [13], "Karma Yemlerin Genetik Algoritmayla Maliyet Optimizasyonu" adlı çalışmasında hayvanların yetiştirme şeklini, türünü, yaşını, ihtiyaçlarını ve yem maliyetlerini dikkate alarak bir program geliştirmiştir. $\mathrm{Bu}$ şekilde yem karışımını genetik algoritma ile optimize etmeye çalışmıştır. Bu yöntemle hammadde kaynaklarından en verimli şekilde yararlanılarak hayvan ihtiyaçlarına karşılık 
gelebilecek en uygun üretimi en uygun fiyat ile gerçekleştirmek amaçlanmıştır. Tekerli (2010) [14], Ege Bölgesi karma yem sanayinin mevcut durumunun incelenmesi ve geliştirilmesi üzerine bir araştırma yapmıştır. Bu çalışmada Ege Bölgesinde bulunan karma yem işletmelerinin var olan durumu ayrıntılarıyla ele alınmış ve bölgedeki karma yem sanayisinin teknik açıdan analiz edilip geliştirilmesi adına öneriler sunulmuştur. Çalışmada Ege Bölgesinde yer alan yem işletmelerinin 41 tanesine anket uygulanmış ve ulaşılan veriler analiz edilmiştir. İncelemeler sonucunda karma yem işletmelerinin hammadde ve nitelikli işgücü temini, üretimde yaşanan kalite kontrol eksikliği ve teknolojik yeniliğe açık olmama gibi problemleri olduğu belirlenmiştir. Csikai (2011) [15], çalışmasında tedarikçi kalite yönetimi ve yem formülasyonu arasındaki entegrasyonun; daha tutarlı ürün kalitesi, daha düşük rasyon maliyetleri, planlamada doğruluk, bileşen satın alma kararlarında destek, daha iyi izlenebilirlik, tedarikçi performansının iyileştirilmesi ve iç kalite yönetim süreçlerinin daha faydalı hale gelmesine yol açtığı sonucuna ulaşmıştır. Yaşar ve Durmuş (2014) [16], çalışmalarında farksal gelişim algoritması kullanarak karma yem maliyet optimizasyonu üzerine çalışmışlardır. Çalışmada tavşan büyütme yemi dikkate alınarak hazırlanan rasyon hesabına ilişkin hayvanın besin ihtiyaçlarını karşılayacak düşük maliyetli olan uygun yem karışımlarını üretmek amaçlanmıştır. Sonuçlara göre; farksal gelişim algoritması ile karma yem maliyetinin düşürüldüğü gözlemlenmiştir. Denli vd. (2015) [2], çalışmalarında Diyarbakır ilindeki toplam 14 yem fabrikası ile anket çalışması yürütmüşler; ham madde temini, üretim, kalite, teknik altyapı, kapasite kullanım durumu, pazarlama koşulları gibi mevcut sorunları belirleyerek çözüm önerilerinin sunulmasını amaçlamışlardır. Çalışma sonucunda; yem fabrikalarının sahip olduğu teknik donanımlarının yeterli olduğunu, laboratuvar altyapılarının bulunmadığını ve laboratuvar kurma isteklerinin bulunduğunu, kurulu kapasitelerinin yeterli olduğunu ancak bir tanesi hariç diğerlerinin tek vardiya üretim yaptıklarını belirlemişlerdir. Elleuch, Dafaoui, El Mhamedi ve Chabchoub (2016) [17], çalışmalarında günde 500 ton üretim ile hayvancılık için karma yem ürünleri üreten bir tarımsal gıda şirketi için, güvenlik açıkları ile başa çıkmaya yardımcı olan bir yöntem geliştirmeyi ve tedarik zincirinin esneklik kapasitelerini arttırmak için prosedüre dayalı bir kalite fonksiyonu göçerimi sağlamayı amaçlamışlardır. Gülsün ve Miç (2018) [18] ise, rasyon hazırlamada temel yem miktarlarının ekonomik olarak belirlenmesi için çok amaçlı programlama yaklaşımı kullanmışlardır. Çalışmada, yem ihtiyacı için belirli bir sermaye miktarını geçmeden, belirli bir hayvan sayısı ve günlük süt üretim miktarının altına düşmeden, bazı kısıtları sağlayarak matematiksel model çözümüyle optimum yem karmasını bulmak amaçlanmıştır.

$\mathrm{Bu}$ çalışmada ise, literatürde yer alan çalışmalardan farklı olarak yem üretimi yapan bir işletmede kalite, fiyat, paket/ ambalaj, dağıtım gibi alanları birlikte değerlendirecek biçimde kalite fonksiyonu göçerimi yöntemi kullanılmıştır. Bir yem fabrikası için müşteri ihtiyaçları ile teknik ihtiyaçların tanımlanması, değerlendirilmesi ve birleştirilmesi ilgili sektör için de örnek oluşturmaktadır. Kalite fonksiyonu göçerimi ile yaşanan sıkıntılara çözüm önerileri geliştirmek için müşteri gereksinimlerini en iyi şekilde ifade ederek çözümlemek ve bu sayede işletmenin piyasada rekabet üstünlügünü sağlaması hedeflenmektedir. Müşteri istekleri bilincine dayanan sistematik bir yaklaşım olması bu yöntemin seçilmesinin ana nedenidir. 


\section{Kalite fonksiyonu göçerimi}

Kalite Fonksiyonu Göçerimi; (Quality Function Deployment, QFD), 1960'l1 yılların sonlarında, İkinci Dünya Savaşı'ndan sonra Japon endüstrilerinin orijinalliğe dayalı ürün geliştirmeye geçtiği bir dönemde, Japonya'da tasarlanmıştır [19]. 1970'li yıllarda Toplam Kalite çatısı altında yeni ürün geliştirme için kavram veya bir yöntem olarak doğmuştur. Shigeru Mizuno ve Yoji Akao tarafindan yazılan KFG hakkındaki ilk kitap olan "Kalite Fonksiyonu Göçerimi”; “Toplam Kalite Kontrolüne Bir Yaklaşım” olarak eklenmiştir [20]. KFG'nin ilk kullanıcıları arasında Toyota, Ford Motor Company, Procter, 3M Corporation, Gamble, AT\&T, Hewlett Packard, Digital Equipment Corporation, vb. yer almaktadır. Toyota'nın KFG kullanarak 1977'den 1984'e kadar üretim öncesi maliyetlerini \%60 oranında azaltabildiği ve geliştirilmesi için gereken süreyi üçte bir oranında azaltabildiği gözlenmiştir Ayrıca, KFG'nin kavramsal bir haritası olan kalite evi (House of Quality (HoQ)), son yillarda üretim ve hizmet alanlarında yaygın olarak kullanılmıştır [21]. KFG'nin otomotiv, bankacılık, iletişim, inşaat, gıda, sağlık hizmeti, ulaştırma, metal ve makine, satış ve pazarlama, tekstil, proje yönetimi ve planlama gibi pek çok alanda uygulaması yapılmıştır [22].

Kalite fonksiyonu göçerimi kalite yönetimi içinde müşteri gereksinim ve isteklerinin firmanın bütün fonksiyonel bileşenlerindeki ürün ya da hizmet teknik karakteristiklerine dönüştürülmesini sağlayan anlaşılması kolay ve çok disiplinli olarak yürütülen bir yöntemdir [23]. Müşteri istekleri bilincine dayanan tasarım tabanlı sistematik bir yaklaşımdır ve kurumsal fonksiyonel grupların entegrasyonu ile yürütülür [24]. Belli bir sistematik içinde iyileştirme, ürün planlama, karşılaştırma, geliştirme vb. aşamalarla müşteri gereksinim ve isteklerini pazarlamaya kadar karşılamayı sağlar [25]. Başka bir deyişle, KFG bir dizi planlama aracı olarak görülebilir. Müşteri memnuniyetine odaklanarak yeni veya geliştirilmiş ürünlerin pazara daha hızlı sunulmasına yardımcı olur [21]. KFG ile "müşterilerin sesi" (Voice of Customer, VoC,) teknik gereksinimlere çevrilebilmektedir. Birçok endüstride ürün tasarımı, karar verme süreci, müşteri memnuniyeti ve performansın önceliklendirilmesini sağlamak amacıyla başarılı bir şekilde uygulanmıştır [26].

KFG ile kalite evi olarak bilinen bir matris oluşturulmaktadır. $\mathrm{Bu}$ matris girdi-çıktı stratejisini temel alan süreci tarif etmeye hizmet eder. Altında yatan temel "ne" ile açıklanan müşteri gereksinimleri listesinden ve gereksinimlerin "nasıl" karşılanacağı ile ilgili düşünceleri (ürün özellikleri) açıklayan teknik gereksinimler listesinden eş zamanlı yararlanmadır [27]. Kalite evinin yardımıyla; hangi parça ya da malzemelerin hangi üretim yöntemleri ile kim tarafından kullanılacağı belirlenmeye çalışılır. Ayrıca; nasıl, nerede, hangi araçlarla, ne zaman, ne kadar karşılanacak sorularına da yanıt aranır. Bu sayede müşteri gereksinimleri ve istekleri detaylandırılmış ve en genelden en küçük ayrıntıya kadar aktarılmış ve yayılmış hale getirilmektedir [28].

Kalite evinin temel yapısı Şekil 1'de gösterilmiştir [29]. 


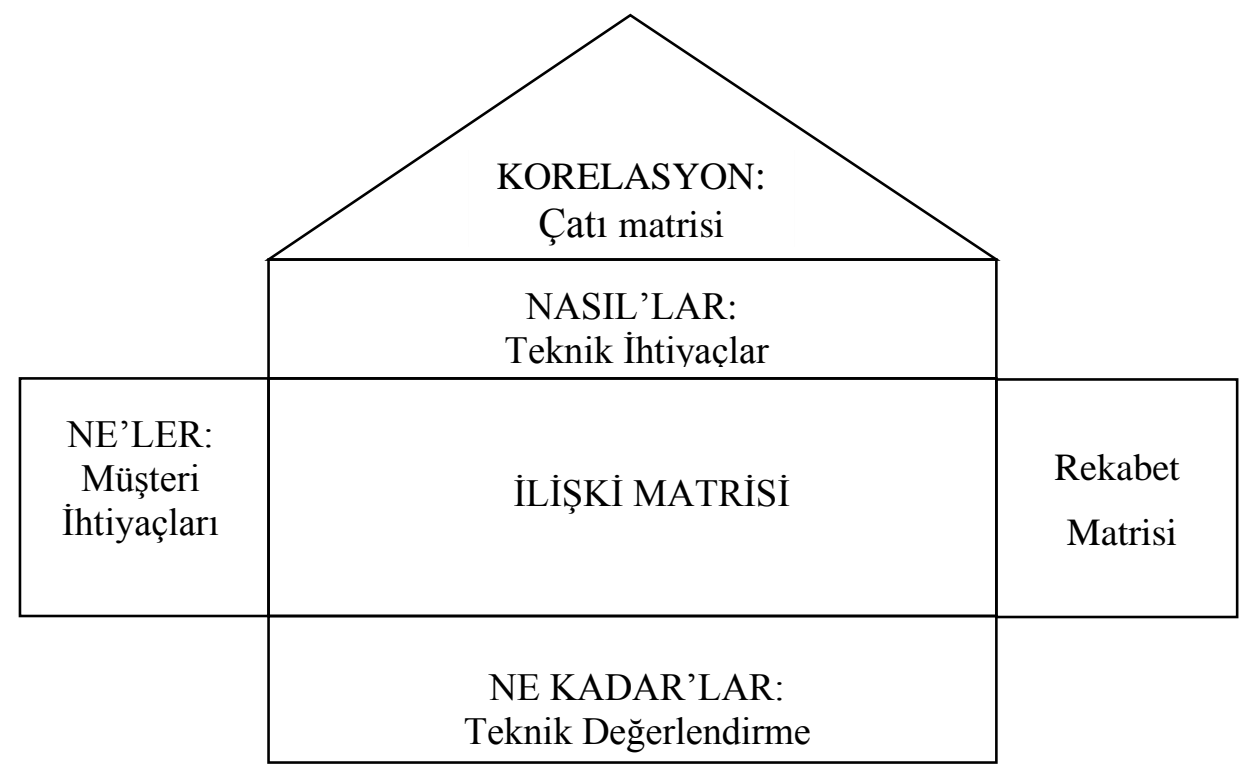

Şekil 1. Kalite evinin temel yapısı.

Kalite evi müşterinin sesini kapsamaktadır ve bu nedenle KFG sürecinde kritik bir rol üslenmektedir. KFG, farklı aşamalarla elde edilen matrislerden oluşturulmaktadır [22]:

Aşama 1: Müşterinin Gereksinimlerinin ve İstekleri ile Önem Derecelerinin Belirlenmesi: Birinci aşamada "Ne'ler (What's)" olarak ifade edilen, müşteri gereksinimlerinin; müşterilerin ürün ya da ürün özelliklerine ilişkin isteklerinin açıklanması sağlanmaktadır. Bu gereksinimlerin tüketicilerin kendi kelimeleri ile ifade edilmesi önemlidir [30].

KFG, karar vericilere öncelik verme konusunda yardımcı olmak için Analitik Hiyerarşi Prosesi (AHP) ile entegre edilebilmektedir. AHP kullanılarak müşteri gereksinimlerinin öncelikleri tanımlanmaktadır. AHP kullanımıyla hem kararın tutarlılığının ölçümü sağlanmakta hem de yargılama sürecinin analitik prosedürü ölçüm skalası ile gerçekleştirilebilmektedir. Yapılan eşleştirmeler ile müşteri gereksinimlerinin bir diğerine göre ne kadar önemli olduğu karşılaştırılarak belirlenmektedir [26].

Müşteri gereksinimleri için kombinasyon halinde eşleştirilmiş karşılaştırmalar hiyerarşik yapı ile ölçüm elde etmede çok fayda sağlamaktadır. Ayrıca, burada müşterilerin yapacakları karşılaştırmaların deneyim veya eğitim yoluyla hafızada belirlenen standartlar temelinde yapılacağı öngörülmektedir. Karşılaştırmada 1'den 9'a kadar değerler kullanılmaktadır. 1, eşit önemli olarak değerlendirilirken; 9, kuvvetli düzeyde daha önemli anlamına gelmektedir [31].

Önem derecelerinin belirlenmesi için grup karar alma sürecinde bütünleştirilmiş yarg1 matrisi oluşturulmasında geometrik ortalama yaklaşımı kullanılması önerilmektedir. $\mathrm{Bu}$ nedenle karşılaştırma sonucunda öncelikle elde edilen değerlerin geometrik ortalaması alınarak yargılar birleştirilmektedir ve $a_{i j}$ ile sembolize edilmektedir [32]. Geometrik ortalama değerleri kullanılarak elde edilen karşılaştırma matrisi $A=\left(a_{i j}\right), a_{i j}=$ $\frac{1}{a_{j i}}$ özelliğini sağlamaktadır [31]. Her bir kriterin eşit değerlendirilmesi için Eşitlik (1)'de verildiği şekilde normalizasyon yapılmakta ve her bir kriterin ağırlığı yani önem düzeyi $p$ (priority) Eşitlik (2)'deki denkleme göre belirlenmektedir [33]: 
$b_{i j}=a_{i j} /\left(\sum_{i=1}^{n} a_{i j}\right) \quad i, j=1 \ldots \ldots n$.

$p_{i}=\left(\sum_{i=1}^{n} b_{i j}\right) / n \quad i, j=1 \ldots \ldots$.

Analitik Hiyerarşi Prosesinde önem düzeylerinin belirlenmesinden sonra yapılan tüm karşılaştırmaların tutarlılıkları (CR) kontrol edilmektedir. Burada $n$ alt kriterde yer alan müşteri ihtiyacı sayısı, $\lambda_{\text {enb }}$ karşılaştırma matrisinin en büyük özdeğeridir. $R I$ değeri $\mathrm{n}=4$ iken $0.9,7$ iken; 1.32 ve 8 iken 1.41 olmaktadır. Tutarlılık hesaplaması Eşitlik (3)'te verilen formüle göre yapılmaktadır [31, 34]:

$\left.C R=\left[\left(\lambda_{\text {enb }}-n\right) / n-1\right)\right] / R I$

Burada $C R<0.1$ ise ikili karşılaştırma matrisi tutarlı kabul edilmektedir [33].

Aşama 2: Teknik Gereksinimlerin ve Korelasyonların Belirlenmesi: Müşteri isteklerinin toplanmasından sonraki en önemli aşama müşterinin bu isteklerinin işletme diline çevrilmesidir. Burada istekler teknik gereksinimlere yani Nasıl'lara (How's) dönüştürülmektedir [35]. $\mathrm{Bu}$ dönüşümde korelasyon yani çatı matrisi, teknik karakteristiklerin iç ilişkilerini göstermek amacıyla kullanılmaktadır. Her bir hücre, iki karakteristik arasındaki korelasyonu ifade eder ve hücreler bir çatı oluşturur. İki karakteristik arasındaki güçlü pozitif ilişki pozitif korelasyonu ve birbirleriyle uyuştuklarını, güçlü negatif ilişki de negatif korelasyonu ve birbirleriyle zıt düştüklerini [36].

Aşama 3: Müşteri İhtiyaçları ile Teknik Gereksinimler Arasındaki İlişkinin Belirlenmesi: $\mathrm{Bu}$ aşama belirlenen müşteri ihtiyaçları ile teknik karakteristiklerin birbirleriyle ilişsilerinin düzeylerinin belirlenmesini kapsamaktadır. Burada ilişkiden kastedilen, her satırdaki müşteri isteğini yani ne'lerin her sütunda yer alan teknik karakteristiklerle yani nasıl'larla, karşılamadaki etkisinin belirlenmesidir [37]. Burada ilişkiler için $R_{i j}$ ilişki matrisi puanı belirlenir. Bu puanların belirlenmesinde semboller kullanılır. $\bullet$ sembolü güçlü ilişki ve 9 puan, o sembolü orta ilişki ve 3 puan temsilini sağlarken; $\Delta$ sembolü zayıf ilişki ve 1 puan karşılığına gelmektedir [29].

Aşama 4: Teknik Gereksinimlerin Önem Derecelerinin belirlenmesi: Bu aşamada her bir teknik gereksinimin ilişki matrisinde tanımlanan değerleri puanlanır ve öncelik sıralaması belirlenir [38]. Puanlamada $m$ müşteri ihtiyacı ve $n$ teknik karakteristik için $T_{i}$ müşteri ihtiyaçları önem derecesini ifade ettiğinde teknik önem seviyesi $w_{j}$ Eşitlik (4)'de, Normalize Edilmiş Değer ise Eşitlik (5)'de verildiği şekilde hesaplanır [39]:

$w_{j}=\sum_{i=1}^{m} R_{i j} x T_{i}$

$\dot{w}_{J}=\frac{w_{j}}{\sum_{j=1}^{n} w_{j}}$

Aşama 5: Rekabet Analizinin Gerçekleştirilmesi: Rekabet analizinin gerçekleştirilmesinde hazırlanan rekabet matrisi, işletme beklentileri göz önünde bulundurularak işletmenin ürünleri ile rakip ürün veya ürünler arasındaki fark1 gösterir. Böylece işletmenin piyasadaki eksik ve üstün yönleri belirlenir. Bu matris kalite evinin sağındaki sütunlara yerleştirilir [40]. 
Bu aşamada hem araştırılan firma hem de rakip firma için müşteri ihtiyaçlarını karşılama oranını ifade etmek gerekmektedir. Bunun için 5'li skala değerlendirilmesi yapılabilmektedir. (1: çok kötü, 5: çok iyi). Her bir ihtiyaç için iyileştirme oranının (IO) belirlenmesinde Eşitlik (6)'te verildiği gibi belirlenen hedefin $(B H)$ şu an için firmadan duyulan memnuniyet düzeyine ( $F B$, firmanın bugünü) oranı alınmaktadır [41]:

$$
\dot{\mathrm{I} O}{ }_{i}=\frac{B H_{i}}{F B_{i}}
$$

Rekabet matrisinde yer alan satış puanı bölmesi $(S P)$, firmanın beklentilerine göre değişkenlik göstererek 3 farklı değer alabilir. Yapılacak iyileştirmeler doğrultusunda beklenti satışların önemli düzeyde artışı yönündeyse 1.5; satışların sadece artış1 yönündeyse 1.2; yapılacak iyileştirmeler sonucunda satışlar düzeyinde herhangi bir değişiklik meydana getirmeyeceği yönündeyse 1.0 puanlama yapılır.

Satış puanının da belirlenmesinden sonra önem puanı hesaplanır. Müşteri gereksinimlerinin firma için ne derece önemli olduğu hesaplanan önem puanı ile görülebilmektedir. Her bir ihtiyaç için önem puanının (ÖNEMP) belirlenmesinde Eşitlik (7) kullanılır [41]:

$\ddot{O} N E M P_{i}=\dot{\mathrm{I} O}{ }_{i} \mathrm{X} S P_{i}$

Daha sonra bu değer normalize edilir. Normalize edilmiş önem puanı (NÖNEMP) Eşitlik (8)'de verildiği ş̧ekilde belirlenir [30].

$N O ̈ N E M P_{i}=\frac{\ddot{O} N E M P_{i}}{\sum_{i=1}^{n} \operatorname{ÖNEMP}_{i}}$

\section{Uygulama}

Bu çalışma Balıkesir merkezli, temelleri 1968 yılına dayanan ancak üretime 1989 yılında başlayan bir yem fabrikasında gerçekleştirilmiştir. İşletme 30'u aşkın çeşitte yem üretimi yapmaktadır. Üretilen yem çeşitleri; buzağı yemleri, süt yemleri, besi yemleri, özel dönem yemleri, küçükbaş yemleri, kanatlı yemleri, yumurta yemleri ve damızlık yem grupları olmak üzere farklı başlıklar altında çeşitlilik göstermektedir. Yem üretiminde çoğunlukla büyükbaş ve kanatlı yemine ağırlık verilmektedir.

Günlük 900 tonu aşkın yem üretim kapasitesine ve 950 ton sevkiyata sahiptir. 2018 yılında 198000 ton yem üretimi gerçekleşmiştir. İşletmede 18 adet mamul silosu ve 22 adet hammadde silosu bulunmaktadır. İşletmenin filosunda sevkiyatta kullanılan 12'den fazla araç bulunmakta olup 150'den fazla bayi ile çalışmaktadır.

\subsection{KFG ekibinin oluşturulması ve müşsterinin tanımlanması}

Kalite Fonksiyonu Göçerimi ekibi yem üretim işletmesinin müdürü, üretim şefi, depo ve sevkiyat sorumlusu ve pazarlama müdüründen oluşmaktadır. İşletmenin farklı departmanlarından çalışanlarının da fikir ve önerilerine başvurulmuştur. Gerektiği durumlarda farklı departmanlardan çalışanların da KFG ekibine katılımları sağlanmıştır. KFG ekibi ile yapılan görüşmeler sonucunda müşteri grubunun bu işletmenin yemini kullanan, tercihini bu yem üretim işletmesinden yana kullanan müşteriler olması yönünde 
karar alınmıştır. $\mathrm{Bu}$ müşteri grubunun seçilmesinin nedeni yem kullanımının tüm süreçlerinde birebir ürünü deneyimleyen, sonuçları gözlemleyen kişiler olmalarıdır.

\subsection{Müşteri gereksinimlerinin ve istekleri ile önem derecelerinin belirlenmesi}

$\mathrm{Bu}$ araştırmada, yem üretim işletmesi ve tüm çalışma süreçleri ayrıntılarıyla yerinde incelenmiştir. Oluşturulan KFG ekibi ile birlikte gemba analizi sırasında ve müşteri grubu ile yapılan derinlemesine görüşmeler sonucunda müşteri istekleri toplanmış ve gruplandırılmıştır. Yem üretim işletmesine ait belirlenen müşteri grubuyla yapılan görüşmeler sonucunda 22 adet müşteri isteği tanımlanmış ve bu istekler, kalite, fiyat, paket/ ambalaj ve dağıtım olmak üzere 4 ana grupta toplanmıştır. Gerçekleştirilen görüşmeler neticesinde toplanan müşteri ihtiyaçları Tablo 2'de listelenmiştir.

Tablo 2. Müşteri ihtiyaçları.

\begin{tabular}{|c|c|c|}
\hline Gruplar & Kod & İhtiyaçlar \\
\hline \multirow{7}{*}{ Kalite } & İ1 & Besin, Protein vb. Değerlerin Yüksek Olması \\
\hline & İ2 & Kullanma Talimatlarının (Ölçeklerinin) Belirtilmesi \\
\hline & $\dot{\mathrm{I}} 3$ & Kullanıcılara Ek Bilgi (Tavsiyeler) Sunması (İnternet vb.) \\
\hline & I4 & Yeterli Teknik Düzey ve Elemana Sahip Olması \\
\hline & $\dot{\mathrm{I}} 5$ & Üretimde Yabancı Maddelerin Önlenmesi (Dikiș iğnesi, İp vb.) \\
\hline & İ6 & Üretilen Yemin Her Aşamada İzlenebilir Olması \\
\hline & İ7 & HACCP Şartlarına Uygun Üretim Yapılması \\
\hline \multirow{4}{*}{ Fiyat } & $\dot{\mathrm{I}} 8$ & Bütçeye Uygun Fiyat \\
\hline & İ & Ödeme Kolaylığı Sağlaması \\
\hline & $\dot{\mathrm{I}} 10$ & Promosyonlu Fiyat Uygulamas1 Yapılmas1 \\
\hline & $\dot{\mathrm{I}} 11$ & Opsiyon Tanınması \\
\hline \multirow{7}{*}{$\begin{array}{c}\text { Paket/ } \\
\text { Ambalaj }\end{array}$} & $\dot{\mathrm{I}} 12$ & Paketin Kolay Açılması \\
\hline & $\dot{\mathrm{I}} 13$ & Paketin Dayanıklı Olması (Patlama, Sızdırma Olmaması) \\
\hline & $\dot{\mathrm{I}} 14$ & Ekolojik Paket Kullanılması \\
\hline & $\dot{\mathrm{I}} 15$ & Her Pakette Ürün Bilgilerini İçeren Etiket Bulunması \\
\hline & $\dot{\mathrm{I}} 16$ & Paket Üzerinde İçindeki Yemin Net Değerinin Belirtilmesi \\
\hline & $\dot{\mathrm{I}} 17$ & Ambalajın Yemin Yoğunluğuna Göre Yapılması \\
\hline & $\dot{\mathrm{I}} 18$ & Paketlerde Boya Bask1 ve Ebatların Standartlara Uygun Olmas1 \\
\hline \multirow{4}{*}{ Dağıtım } & $\dot{\mathrm{I}} 19$ & Yaygın Dağıtım Ağının Olması \\
\hline & $\dot{\mathrm{I}} 20$ & Nakliye Kolaylı̆̆ \\
\hline & $\dot{\mathrm{I}} 21$ & Teslimatın Zamanında Gerçekleşmesi \\
\hline & $\dot{\mathrm{I}} 22$ & Dağıtımda Yemin Ufalanmasının/ Ezilmesinin Önlenmesi \\
\hline
\end{tabular}

Yapılan gemba analizleri ve belirlenen müşteri grubuyla yapılan görüşmeler sonucu anket ve karşılaştırma formu hazırlanmış ve uygulanmıştır. Bunun için uygulamanın gerçekleştiği karma yem işletmesinin rassal olarak belirlenmiş 26 müşterisine anket yapılmıştır. Toplamda 26 müşteriye demografik özelliklerin belirlenmesi için çoktan seçmeli soru sorulmuş ve AHP yöntemine uygun olarak ihtiyaçlara ilişkin 60 karşılaştırma yapmaları istenmiştir.

Müşterilere ilişkin demografik bilgiler aşağıda verilen Tablo 3 ’te sunulmaktadır. 
Tablo 3. Demografik özellikler.

\begin{tabular}{|c|c|c|c|}
\hline & & Frekans & Yüzde \\
\hline \multirow{2}{*}{ Cinsiyet } & Kadın & 3 & 11.5 \\
& Erkek & 23 & 88.5 \\
\hline \multirow{3}{*}{ Öğrenim } & İlk-Orta & 1 & 3.8 \\
Durumu & Lise & 11 & 42.3 \\
& Lisans & 10 & 38.5 \\
& Lisansüstü & 4 & 15.4 \\
\hline & $16-24$ & 1 & 3.8 \\
Yaş & $25-30$ & 2 & 7.7 \\
& $31-35$ & 5 & 19.2 \\
& $36-45$ & 10 & 38.5 \\
Aylık & 45 Üstü & 8 & 30.8 \\
Ortalama & $1301-2000$ & 2 & 7.7 \\
Gelir & $2001-3500$ & 2 & 7.7 \\
\hline & $>3500$ & 22 & 84.6 \\
Büyükbaş & $<10$ & 2 & 7.7 \\
Hayvan & $11-25$ & 3 & 11.5 \\
Sayısı & $26-44$ & 2 & 7.7 \\
& $45-50$ & 7 & 26.9 \\
& $>50$ & 12 & 46.2 \\
\hline \multirow{2}{*}{ Küçükbaş } & $<10$ & 5 & 19.2 \\
Hayvan & $11-25$ & 6 & 23.1 \\
Sayısı & $26-44$ & 4 & 15.4 \\
& $45-50$ & 5 & 19.2 \\
& $>50$ & 6 & 23.1 \\
\hline
\end{tabular}

Tablo 3'te verilen bilgilere göre; müşterilerin büyük bölümü erkektir (23). Büyük çoğunluğunun (\%80.8) öğrenim durumu lise ve lisans düzeyindedir. Büyük çoğunluğundaki (\%73.1) büyükbaş hayvan sayısı 45 üzerindedir. \%57.7'sinin küçükbaş hayvan sayısı 45 'in altındayken \%42.3'ünün 45 üzeridir.

Müşterilerin sübjektif ve niteliksel fikirleri ve isteklerinin sayısal kriterlere dönüştürülmesinde Analitik Hiyerarşi Prosesi kullanılmıştır. Müşteri memnuniyetini arttıran ve müşteri tercihlerine etki eden en önemli faktörlerin önem derecelerinin belirlenmesinde 4 grup üzerinden 22 kriterden oluşan 60 karşılaştırma yapılmıştır. Formun en sonunda 4 gruba ilişkin ana kriterler kendi aralarında karşılaştırılmıştır. AHP için kullanılan form EK 1'de verilmektedir. Müşterilerin karşılaştırmalarının birleştirilmesinde geometrik ortalama kullanılmıştır.

AHP yöntemi ile öncelikle Eşitlik (1) ve Eşitlik (2)'de verilen işlemler uygulanmış ve önem dereceleri belirlenmiştir. Daha sonra karşılaştırmaların tutarlılıkları kontrol edilmiştir. AHP içinde yer alan ana kriterlere ilişkin önem dereceleri yani ağırlıklar; Kalite için 0.52, Fiyat için 0.36, Paket için 0.04 ve Dağıtım için 0.08 olarak elde edilmiştir.

Müşteri ihtiyaçlarının yani alt kriterlerin global önem derecesine göre sıralaması Tablo 4 'te verilmiștir. 
Tablo 4. İhtiyaçların önem dereceleri.

\begin{tabular}{|c|c|c|}
\hline Kod & İhtiyaçlar & $\begin{array}{c}\text { Önem } \\
\text { Derecesi }\end{array}$ \\
\hline$\dot{\mathrm{I}} 21$ & Teslimatın Zamanında Gerçekleşmesi & 0.55 \\
\hline$\dot{\mathrm{I}} 1$ & Besin, Protein vb. Değerlerin Yüksek Olması & 0.41 \\
\hline İ8 & Bütçeye Uygun Fiyat & 0.40 \\
\hline$\dot{\mathrm{I} 9}$ & Ödeme Kolaylığı Sağlaması & 0.29 \\
\hline$\dot{\mathrm{I}} 16$ & Paket Üzerinde İçindeki Yemin Net Değerinin Belirtilmesi & 0.27 \\
\hline$\dot{\mathrm{I}} 15$ & Her Pakette Ürün Bilgilerini İçeren Etiket Bulunması & 0.22 \\
\hline$\dot{\mathrm{I}} 22$ & Dağıtımda Yemin Ufalanmasının/ Ezilmesinin Önlenmesi & 0.21 \\
\hline İ7 & HACCP Şartlarına Uygun Üretim Yapılması & 0.19 \\
\hline$\dot{\mathrm{I}} 17$ & Ambalajın Yemin Yoğunluğuna Göre Yapılması & 0.18 \\
\hline$\dot{\mathrm{I}} 5$ & Üretimde Yabancı Maddelerin Önlenmesi (Dikiș iğnesi, İp vb.) & 0.17 \\
\hline$\dot{\mathrm{I}} 13$ & Paketin Dayanıklı Olması (Patlama, Sizdırma Olmaması) & 0.17 \\
\hline$\dot{\mathrm{I}} 10$ & Promosyonlu Fiyat Uygulamas1 Yapılması & 0.16 \\
\hline İ11 & Opsiyon Tanınması & 0.16 \\
\hline$\dot{\mathrm{I}} 4$ & Yeterli Teknik Düzey ve Elemana Sahip Olması & 0.14 \\
\hline$\dot{\mathrm{I}} 19$ & Yaygın Dağıtım Ağının Olması & 0.14 \\
\hline$\dot{\mathrm{I}} 20$ & Nakliye Kolaylığı Sunması & 0.10 \\
\hline$\dot{\mathrm{I}} 18$ & Paketlerde Boya Bask1 ve Ebatların Standartlara Uygun Olmas1 & 0.07 \\
\hline$\dot{\mathrm{I}} 14$ & Ekolojik Paket Kullanılması & 0.06 \\
\hline$\dot{\mathrm{I}} 2$ & Kullanma Talimatlarının (Ölçeklerinin) Belirtilmesi & 0.04 \\
\hline$\dot{\mathrm{I}} 3$ & Kullanıc1lara Ek Bilgi (Tavsiyeler) Sunması (İnternet vb.) & 0.03 \\
\hline$\dot{\mathrm{I}} 12$ & Paketin Kolay Açılması & 0.03 \\
\hline İ6 & Üretilen Yemin Her Aşamada İzlenebilir Olması & 0.02 \\
\hline
\end{tabular}

Tablo 4'e göre teslimatın zamanında gerçekleşmesi (0.55) ve besin, protein vb. değerlerin yüksek olması (0.41) isteği en yüksek önem düzeyine sahiptir. Bütçeye uygun fiyat beklentisi (0.40) üçüncü sırada yer almaktadır. Üretilen yemin her aşamada izlenebilir olması (0.02) beklentisi en düşük önem düzeyine sahiptir.

\subsection{Teknik gereksinimlerin ve korelasyonların belirlenmesi}

KFG ekibi ve yem firması uzman görüşleri sonucunda oluşturulan 22 adet teknik karakteristik bilgisi Tablo 5'te verilmiştir.

Tablo 5. Teknik karakteristikler.

\begin{tabular}{|c|c|}
\hline Kod & Teknik Karakteristik \\
\hline TK1 & Uygun Hammadde Kullanımı \\
\hline TK2 & Kullanım Kitapçı̆̆1 Hazırlanması \\
\hline TK3 & Web Sitesi Uygulamalı Videolar \\
\hline TK4 & Eğitim Programları Düzenlenmesi \\
\hline TK5 & Kalite Kontrol Noktaları Oluşturulmas1 \\
\hline TK6 & Ürün Takip Sistemi Oluşturulmas1 \\
\hline TK7 & HACCP Ekibi Oluşturulması \\
\hline TK8 & Fiyat Standardizasyonu \\
\hline TK9 & Kredi Kartı İle Taksitlendirme \\
\hline
\end{tabular}


Tablo 5. (Devami).

\begin{tabular}{|c|c|}
\hline TK10 & Ödeme Şekli Fiyat İndirimi \\
\hline TK11 & Vade Değişikliği Fiyat İndirimi \\
\hline TK12 & Kaliteli İp Kullanılması \\
\hline TK13 & Kaliteli Çuval Kullanılması \\
\hline TK14 & Geri Dönüştürülebilir Ambalaj Kullanılması \\
\hline TK15 & Etiket Sistemi Oluşturulması \\
\hline TK16 & Flekso Bask1 Yapılması \\
\hline TK17 & Yoğunluk ve Görselliğe Uygun Ambalaj Çeşitlendirme \\
\hline TK18 & Standartlara Uygun Bask1 \\
\hline TK19 & Bayilik Sayısının Artırılması \\
\hline TK20 & Araç Filosunu Artırmak \\
\hline TK21 & Dağıtım Ağının Sistematikleştirilmesi \\
\hline TK22 & Yemlerin Siparişe Uygun Sıraya Göre Sarılması \\
\hline
\end{tabular}

$\mathrm{Bu}$ çalışmada korelasyon yani çatı matrisinin oluşturulmasında pozitif ilişki: 1 ve negatif ilişki -1 ile sembolize edilmiştir. Elde edilen görünüm Şekil 2'de verilmektedir.

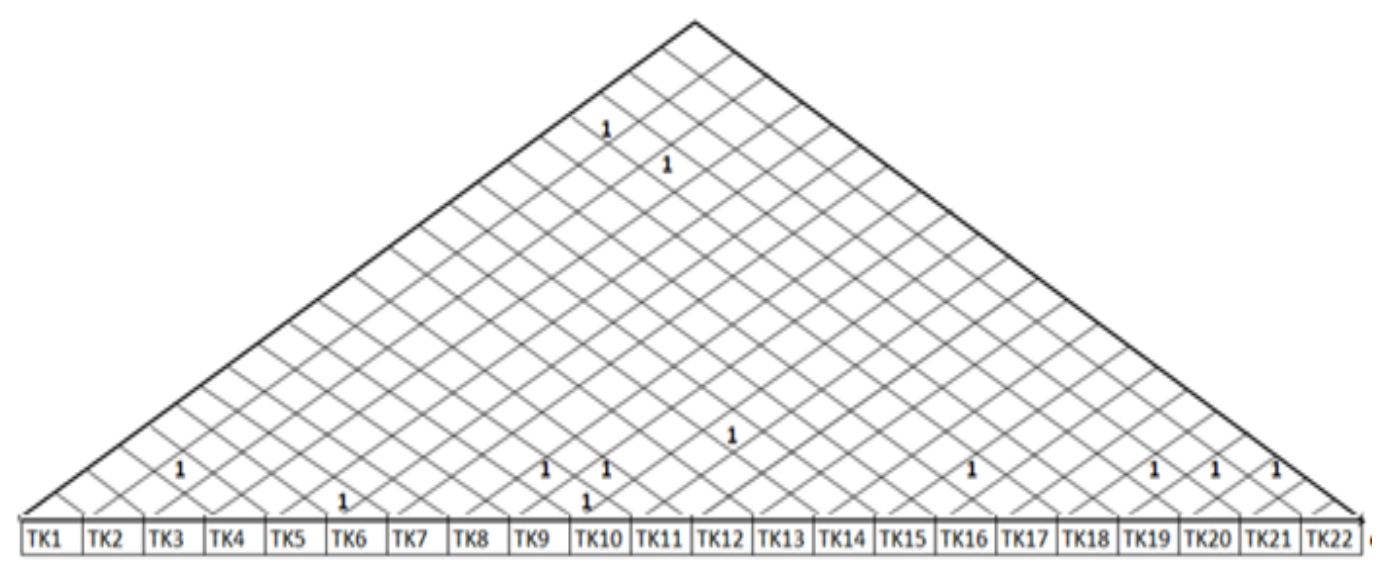

Şekil 2. Çatı matrisi.

Şekil 2.'de verilen çatı matrisine bakıldığında teknik karakteristiklerin uygulanmasında herhangi bir teknik karakteristikle negatif ilişki olmadığı görülmektedir. Eğitim programlarının düzenlemesi ile kullanım kitapçığı hazırlanması arasında pozitif ilişki bulunmaktadır. Düzenlenen eğitim programları ile teknik düzey ve elemana sahip olma sayısını artıracağı için birbirlerine pozitif yönde etki edileceği düşünülmektedir. Araç filosunun artırılması, kalite kontrol sisteminin oluşturulması ile en az hata ile ürün üretimi sağlaması ile müşteri memnuniyetini artıracaktır. Kredi kartı ile taksitlendirme olanağ1 sunması ile ödeme şekli fiyat indirimi arasında pozitif ilişki bulunmaktadır. Ürün takip sistemlerinin oluşturulması ürünü her aşamada izlenebilir kılmasını müşteri güveni sağlaması yönünde pozitif etki yaracaktır.

\subsection{Müssteri ihtiyaçları ile teknik gereksinimler arasındaki ilişkilerin belirlenmesi}

KFG ekibi ve firmanın uzman görüşleri sonucunda incelenen müşteri istekleri ile bu isteklere karşılık gelen teknik karakteristikler arasındaki ilişkiler ve bunlara karşılık gelen sembol değerleri Şekil 3'te gösterilmiştir. Burada en çok ilişkinin bulunduğu karakteristik; TK17 "Yoğunluk ve Görselliğe Uygun Ambalaj Çeşitlendirme"dir. Bu 
karakteristiği TK4 "Eğitim Programları Düzenlenmesi”, TK8 "Fiyat Standardizasyonu", TK9 “Kredi Kartı İle Taksitlendirme”, TK10 “Ödeme Şekli Fiyat İndirimi” izlerken TK 15 "Etiket Sistemi Oluşturulması" için de 3 tane güçlü ilişki bulunmaktadır. Ayrıca; İ9 "Ödeme Kolaylığı Sağlaması” 3 tane güçlü bir tane de zayıf ilişki içermektedir.

\begin{tabular}{|c|c|c|c|c|c|c|c|c|c|c|c|c|c|c|c|c|c|c|c|c|c|c|c|}
\hline & $\begin{array}{l}\text { Önem } \\
\text { Düreyi }\end{array}$ & 药 & 急 & 象 & 药 & 番 & 象 & 2 & $\stackrel{\mathscr{2}}{\ddot{\leftrightarrow}}$ & $\stackrel{2}{2}$ & 象 & $\vec{z}$ & 苂 & $\stackrel{3}{2}$ & $\underset{\mathrm{Z}}{\overrightarrow{2}}$ & 类 & 象 & $\overrightarrow{3}$ & $\stackrel{\infty}{g}$ & 高 & 趈 & $\overrightarrow{\overparen{Z}}$ & 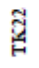 \\
\hline İ21 & 0.55 & & & & & & $\Delta$ & & & & & & & & & & & & & & $\cdot$ & $\cdot$ & 0 \\
\hline II & 0.41 & $\bullet$ & & & & 0 & & & & & & & & & & & & & & & & & \\
\hline İ & 0.40 & $\Delta$ & & & & & & & $\cdot$ & 0 & - & 0 & & & & & & & & & & & \\
\hline í & 0.29 & & & & & & & & $\Delta$ & $\cdot$ & $\cdot$ & $\bullet$ & & & & & & & & & & & \\
\hline İ16 & 0.27 & $\Delta$ & & & & & & & & & & & & & & $\cdot$ & & 0 & $\bullet$ & & & & \\
\hline İ15 & 0.22 & & & & & & & & & & & & & & & $\bullet$ & 0 & $\Delta$ & $\Delta$ & & & & \\
\hline İ22 & 0.21 & & & & $\Delta$ & & & & & & & & & $\bullet$ & & & & 0 & & & & & $\bullet$ \\
\hline İ7 & 0.19 & & & & & & & $\bullet$ & & & & & & & & & & & & & & & \\
\hline İ17 & 0.18 & & & & & & & & & & & & & & 0 & & & $\bullet$ & & & & & \\
\hline I5 & 0.17 & & & & 0 & $\bullet$ & $\Delta$ & & & & & & 0 & & & & & & & & & & \\
\hline I13 & 0.17 & & & & & & & & & & & & & - & & & & 0 & & & & & \\
\hline İ10 & 0.16 & & & & & & & & $\bullet$ & 0 & 0 & 0 & & & & & & & & & & & \\
\hline İl & 0.16 & & & & & & & & 0 & $\Delta$ & $\bullet$ & $\bullet$ & & & & & & & & & & & \\
\hline I4 & 0.14 & & 0 & 0 & $\bullet$ & & & & & & & & & & & & & & & & & & \\
\hline I119 & 0.14 & & & & & & & & & & & & & & & & & & & $\cdot$ & $\cdot$ & 0 & \\
\hline İ20 & 0.10 & & & & & & & & & & & & & & & & & & & 0 & $\bullet$ & $\bullet$ & \\
\hline I18 & 0.07 & & & & & & & & & & & & & & & & $\cdot$ & & $\bullet$ & & & & \\
\hline Il14 & 0.06 & & & & & & & & & & & & & & $\bullet$ & & & & & & & & \\
\hline I2 & 0.04 & & 0 & & & & & & & & & & & & & $\bullet$ & & & & & & & \\
\hline $\mathrm{I} 3$ & 0.03 & & $\bullet$ & & $\bullet$ & & & & & & & & & & & & & & & & & & \\
\hline İl2 & 0.03 & & & & & & & & & & & & $\bullet$ & 0 & & & & & & & & & \\
\hline I6 & 0.02 & & & & & & $\bullet$ & & & & & & & & & & & & & & & & \\
\hline
\end{tabular}

Şekil 3. İlişki matrisi

\subsection{Teknik gereksinimlerin önem derecelerinin belirlenmesi}

Müşteri ihtiyaçları ve bunlara karşılık gelebilecek teknik karakteristikler arasındaki ilişki ve seviyesi KFG ekibi tarafindan oluşturulmuştur. Tablo 6' da teknik karakteristikler ve önem dereceleri verilmiştir. En yüksek önem derecesine sahip teknik karakteristikler ödeme şekli fiyat indirimi ilk sırada yer almaktadır. Bu karakteristiği araç filosunu artırmak, dağıtım ağının sistematik hale getirilmesi ve fiyat standardizasyonu karakteristikleri takip etmektedir.

Tablo 6. Teknik karakteristiklerin önem derecesi ve normalize teknik değerler.

\begin{tabular}{|c|c|c|c|}
\hline Kod & Teknik Karakteristikler & $\begin{array}{c}\text { Teknik } \\
\text { Önem } \\
\text { Seviyesi }\end{array}$ & $\begin{array}{c}\text { Normalize } \\
\text { Edilmiş } \\
\text { Değer }\end{array}$ \\
\hline TK10 & Ödeme Şekli Fiyat İndirimi & 8.13 & 0.11 \\
\hline TK20 & Araç Filosunu Artırmak & 6.51 & 0.088 \\
\hline TK21 & Dağıtım Ağının Sistematikleştirilmesi & 6.27 & 0.085 \\
\hline TK8 & Fiyat Standardizasyonu & 5.81 & 0.079 \\
\hline TK11 & Vade Değişikliği Fiyat İndirimi & 5.73 & 0.078 \\
\hline TK15 & Etiket Sistemi Oluşturulması & 4.77 & 0.065 \\
\hline TK9 & Kredi Kartı İle Taksitlendirme & 4.45 & 0.06 \\
\hline TK1 & Uygun Hammadde Kullanımı & 4.36 & 0.059 \\
\hline
\end{tabular}


Tablo 6. (Devami).

\begin{tabular}{|c|c|c|c|}
\hline TK17 & $\begin{array}{c}\text { Yoğunluk ve Görselliğe Uygun Ambalaj } \\
\text { Çeşitlendirme }\end{array}$ & 3.79 & 0.051 \\
\hline TK22 & Yemlerin Siparişe Uygun Sıraya Göre Sarılmas1 & 3.54 & 0.048 \\
\hline TK13 & Kaliteli Çuval Kullanılması & 3.51 & 0.048 \\
\hline TK18 & Standartlara Uygun Bask1 & 3.28 & 0.044 \\
\hline TK5 & Kalite Kontrol Noktaları Oluşturulmas1 & 2.76 & 0.037 \\
\hline TK4 & Eğitim Programları Düzenlenmesi & 2.55 & 0.031 \\
\hline TK7 & HACCP Ekibi Oluşturulması & 1.71 & 0.023 \\
\hline TK19 & Bayilik Sayısının Artırılması & 1.56 & 0.021 \\
\hline TK16 & Flekso Bask1 Yapplması & 1.29 & 0.018 \\
\hline TK14 & Geri Dönüştürülebilir Ambalaj Kullanılmas1 & 1.08 & 0.015 \\
\hline TK6 & Ürün Takip Sistemi Oluşturulmas1 & 0.9 & 0.012 \\
\hline TK2 & Kullanım Kitapçı̆̆1 Hazırlanmas1 & 0.81 & 0.011 \\
\hline TK12 & Kaliteli İp Kullanılmas1 & 0.78 & 0.011 \\
\hline TK3 & Web Sitesi Uygulamalı Videolar & 0.42 & 0.006 \\
\hline
\end{tabular}

\subsection{Rekabet analizinin gerçekleştirilmesi}

Karma yem üretim işletmesi müşterilerinin ağırlıklı olarak bu bölgede dağılım göstermesi ve alternatif çok fazla karma yem işletmesi bulunması nedeniyle çalışmada rekabet analizi yapılması gerekli görülmüştür. Firmanın ürününü kullanan müşteri ihtiyaçlarını karşılayabilme oranını ifade etmek için 5'li skala değerlendirilmesi kullanılmıştır.

Yapılan rekabete dayalı değerlendirme ile firmanın bugünkü durumu, rakip firmanın durumu ve firmanın iyileştirme oranı belirlenmeye çalışılmıştır. Bunun için kullanılan Rakip Analiz Formu Ek 2'de ve hazırlanan planlama matrisi Tablo 7'de verilmektedir.

Tablo 7. Rekabet matrisi.

\begin{tabular}{|c|c|c|c|c|c|c|c|c|}
\hline $\begin{array}{l}\vec{D} \\
\overrightarrow{1}\end{array}$ & 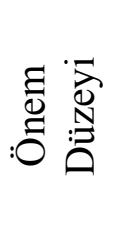 & 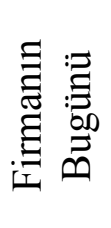 & 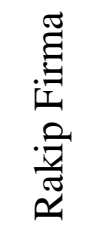 & 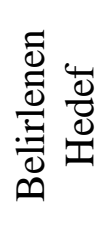 & $\begin{array}{l}\stackrel{\mathscr{E}}{\mathscr{\infty}} \\
\stackrel{\mathbb{E}}{=} \\
\stackrel{\Xi}{\Xi}\end{array}$ & 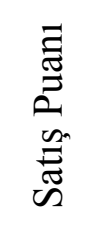 & 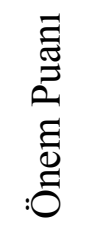 & 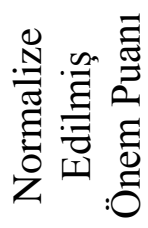 \\
\hline İ21 & 0.55 & 4.82 & 4.03 & 5.00 & 1.04 & 1.50 & 0.86 & 0.15 \\
\hline İ1 & 0.41 & 4.57 & 4.08 & 5.00 & 1.09 & 1.50 & 0.67 & 0.12 \\
\hline İ8 & 0.40 & 3.77 & 4.18 & 4.00 & 1.06 & 1.50 & 0.64 & 0.11 \\
\hline$\dot{\mathrm{I} 9}$ & 0.29 & 4.05 & 4.30 & 5.00 & 1.23 & 1.20 & 0.43 & 0.08 \\
\hline İ16 & 0.27 & 4.51 & 3.87 & 5.00 & 1.11 & 1.00 & 0.30 & 0.05 \\
\hline İ15 & 0.22 & 4.56 & 4.02 & 5.00 & 1.10 & 1.00 & 0.24 & 0.04 \\
\hline İ22 & 0.21 & 4.69 & 3.89 & 5.00 & 1.07 & 1.20 & 0.27 & 0.05 \\
\hline İ7 & 0.19 & 4.30 & 4.26 & 5.00 & 1.16 & 1.50 & 0.33 & 0.06 \\
\hline İ17 & 0.18 & 4.41 & 3.74 & 5.00 & 1.13 & 1.00 & 0.20 & 0.04 \\
\hline$\dot{\mathrm{I} 5}$ & 0.17 & 4.41 & 4.16 & 5.00 & 1.13 & 1.00 & 0.19 & 0.03 \\
\hline İ13 & 0.17 & 4.44 & 4.04 & 5.00 & 1.13 & 1.20 & 0.23 & 0.04 \\
\hline İ10 & 0.16 & 4.29 & 4.17 & 5.00 & 1.17 & 1.50 & 0.28 & 0.05 \\
\hline İ11 & 0.16 & 4.35 & 4.15 & 5.00 & 1.15 & 1.20 & 0.22 & 0.04 \\
\hline İ4 & 0.14 & 4.71 & 3.74 & 5.00 & 1.06 & 1.20 & 0.18 & 0.03 \\
\hline
\end{tabular}


Tablo 7. (Devam1).

\begin{tabular}{|c|c|c|c|c|c|c|c|c|}
\hline$\dot{\mathrm{I}} 19$ & 0.14 & 4.74 & 3.87 & 5.00 & 1.05 & 1.00 & 0.15 & 0.03 \\
\hline$\dot{\mathrm{I}} 20$ & 0.10 & 4.51 & 3.95 & 5.00 & 1.11 & 1.20 & 0.13 & 0.02 \\
\hline$\dot{\mathrm{I}} 18$ & 0.07 & 4.37 & 3.86 & 5.00 & 1.14 & 1.00 & 0.08 & 0.01 \\
\hline$\dot{\mathrm{I}} 14$ & 0.06 & 3.66 & 3.52 & 4.00 & 1.09 & 1.00 & 0.07 & 0.01 \\
\hline$\dot{\mathrm{I}} 2$ & 0.04 & 4.52 & 3.88 & 5.00 & 1.11 & 1.00 & 0.04 & 0.01 \\
\hline$\dot{\mathrm{I}} 3$ & 0.03 & 4.61 & 3.81 & 5.00 & 1.08 & 1.20 & 0.04 & 0.01 \\
\hline$\dot{\mathrm{I}} 12$ & 0.03 & 4.45 & 4.02 & 5.00 & 1.12 & 1.00 & 0.03 & 0.01 \\
\hline$\dot{\mathrm{I}} 6$ & 0.02 & 3.24 & 2.85 & 4.00 & 1.23 & 1.00 & 0.02 & 0.00 \\
\hline
\end{tabular}

Tablo 7.'de bulunan verilere göre bazı istekler için uygulamanın yapıldığı firmanın rakip firmaya göre müşteri beklentisini karşılamada yetersiz olduğu ve firmanın iyileştirmeye gitmesi gerektiği görülmektedir. En öncelikli ele alınması gereken isteklerin; 1.23 iyileştirme oranına sahip "Ödeme kolaylığı sağlanması", "Paket üzerinde içindeki yemin net değerinin belirtilmesi" ve "Üretilen yemin her aşamada izlenebilir olması" olduğu görülmektedir. İyileştirme oranının 1.23 olması firmanın bu beklentileri karşılayabilme konusunda rakip firmanın gerisinde kaldığını ve iyileştirmeler yapması gerektiğini göstermektedir.

\subsection{Kalite evinin oluşturulması}

Kalite evini oluşturmadaki ana görüş; tüketicinin isteklerinin temel fonksiyonların dikkate alınmasıyla çözümlenebilmesidir. Evin içindeki her bir odanın kendine ait fonksiyonu bulunmaktadır [42]. Bütün aşamaların tek tek analiz edilip bir arada birleştirilmesi ile kalite evi meydana gelmiştir. Tüm analizlerin bir arada gösterildiği kalite evi Şekil 4'te verilmiştir. Tüm yapılan analizler, müşteri istekleri ve karşılığında işletmenin bu isteklere nasıl cevap verebileceğini oluşturduğu teknik karakteristikler tek bir çerçevede gösterilmiştir. Bu sayede yem işletmesi bütün analiz, değerleri ve sonuçları tek bir ev üzerinden görebilecektir. 


\begin{tabular}{|c|c|c|c|c|c|c|c|c|c|c|c|c|c|c|c|c|c|c|c|c|c|c|c|c|c|c|c|c|c|c|}
\hline & $\begin{array}{l}\text { Ountu } \\
\text { Dürẹi }\end{array}$ & 5 & 2 & 2 & 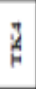 & $\frac{1}{4}$ & $\stackrel{2}{2}$ & $\frac{k}{2}$ & 2 & $\frac{2}{7}$ & $\stackrel{8}{\ddot{H}}$ & $\ddot{z}$ & $\mathbb{Z}$ & $\vec{a}$ & $\begin{array}{l}\Delta \\
\ddot{z}\end{array}$ & $\stackrel{4}{a}$ & $\frac{\mathscr{g}}{d}$ & $\vec{b}$ & $\ddot{a}$ & $\frac{a}{a}$ & $\stackrel{0}{\mathbb{Z}}$ & $\ddot{z}$ & if & Finama & $\begin{array}{l}\text { Rolip } \\
\text { Firmu }\end{array}$ & $\begin{array}{c}\text { Beirlem } \\
\text { Beteff }\end{array}$ & $\begin{array}{c}\text { Irikgut } \\
\text { Ormul }\end{array}$ & $\begin{array}{l}\text { Sutby } \\
\text { Punin }\end{array}$ & \begin{tabular}{l|} 
Ómu \\
Pumu
\end{tabular} & 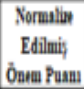 \\
\hline in & 0.55 & & & & & & 8 & & & & & & & & & & & & & & . & $\cdot$ & 0 & 4.82 & 4.03 & 5.00 & 1.04 & 1.30 & 0.86 & 0.15 \\
\hline il & 0.41 & . & & & & 0 & & & & & & & & & & & & & & & & & & 4.57 & 4.08 & 5.00 & 1.09 & 1.50 & 0.67 & 0.12 \\
\hline is & 0.40 & $\Delta$ & & & & & & & . & 0 & $\cdot$ & 0 & & & & & & & & & & & & 3.77 & 4.18 & 4.00 & 1.06 & 1.50 & 0.64 & 0.11 \\
\hline ig & 0.29 & & & & & & & & $\Delta$ & $\cdot$ & $\cdot$ & $\cdot$ & & & & & & $a 1$ & - & & & & & 4.05 & 4.30 & 5.00 & 1.23 & 1.20 & 0.43 & 0.08 \\
\hline i16 & 0.27 & $\Delta$ & & & & & & & & & & & & & & $\cdot$ & & 0 & . & & & & & 4.51 & 3.87 & 5.00 & 1.11 & 1.00 & 0.30 & 0.05 \\
\hline ilis & 0.22 & & & & & & & & & & & & & & & $\cdot$ & 0 & $\Delta$ & 4 & & & & & 4.86 & 4.02 & 8.00 & 1.10 & 1.00 & 0.24 & 0.04 \\
\hline in: & 0.21 & & & & $\Delta$ & & & & & & & & & . & & & & 0 & & & & & . & 4.69 & 3.89 & 6.00 & 1.07 & 1.20 & 0.19 & 0.05 \\
\hline 17 & 0.19 & & & & & & & . & & & & & & & & & & & & & & & & 4.30 & 4.26 & 6,00 & 1.16 & 1.50 & 0.33 & 0.06 \\
\hline 117 & 0.18 & & & & & & & & & & & & & & 0 & & & . & & & & & & 4,41 & 3.74 & 6,00 & 1,13 & 1.00 & \begin{tabular}{l|l}
0.20 \\
\end{tabular} & 0.04 \\
\hline is & 0.17 & & & & 0 & - & $\Delta$ & & & & & & 0 & & & & & & & & & & & 4.41 & 4.16 & 5,00 & 1.13 & 1.00 & 0.19 & 0.03 \\
\hline ilis & 0.17 & & & & & & & & & & & & & . & & & & 0 & & & & & & 4.4 & 4.04 & 5,00 & 1.13 & 1.20 & 0.23 & 0.04 \\
\hline iilo & 0.16 & & & & & & & & $\cdot$ & 0 & 0 & 0 & & & & & & & & & & & & 4.9 & 4.17 & 5,00 & 1.17 & 1.50 & 0.28 & 0.05 \\
\hline ill & 0.16 & & & & & & & & 0 & $\Delta$ & . & $\cdot$ & & & & & & & & & & & & 4.36 & 4.15 & 5,00 & 1.15 & 1.20 & 0.22 & 0.04 \\
\hline it & 0.14 & & 0 & 0 & • & & & & & & & & & & & & & & & & & & & 4.71 & 3.74 & 5.00 & 1.06 & 1.20 & 0.18 & 0.03 \\
\hline 119 & 0.14 & & & & & & & & & & & & & & & & & & & . & . & 0 & & 4.74 & 3.87 & 3.00 & 1.05 & 1.00 & 0.13 & 0.03 \\
\hline 120 & 0.10 & & & & & & & & & & & & & & & & & & & 0 & $\cdot$ & $\cdot$ & & 4.51 & 3.93 & 3.00 & 1.11 & 1.20 & 0.13 & 0.02 \\
\hline I118 & 0.07 & & & & & & & & & & & & & & & & $\cdot$ & & $\cdot$ & & & & & 4.37 & 3.86 & 3.00 & 1.14 & 1.00 & 0.08 & 0.01 \\
\hline II 4 & 0.06 & & & & & & & & & & & & & & . & & & & & & & & & 3.66 & 3.52 & 4.00 & 1.09 & 1.00 & 0.07 & 0.01 \\
\hline i2 & 0.04 & & 0 & & & & & & & & & & & & & $\cdot$ & & & & & & & & 4.52 & 3.88 & 8.00 & 1.11 & 1.00 & 0.04 & 0.01 \\
\hline $\mathrm{b}$ & 0.03 & & . & & . & & & & & & & & & & & & & & & & & & & 4.61 & $\begin{array}{l}3.81 \\
\end{array}$ & 8.00 & 1.08 & 1.20 & 0.04 & 0.01 \\
\hline il: & 0.03 & & & & & & & & & & & & . & 0 & & & & & & & & & & 4.48 & 4.02 & 6,00 & 1.12 & 1.00 & 0.03 & 0.01 \\
\hline 16 & 0.02 & & & & & & • & & & & & & & & & & & & & & & & & 3.24 & 2.86 & 4,00 & 1,3 & 1.00 & 0.02 & 0.00 \\
\hline \multicolumn{2}{|c|}{ Tetal Oven Serivei } & 4.36 & 0.81 & 0.42 & 2,66 & & 0.9 & 1,71 & 6.81 & 4.46 & 8.13 & 6,73 & 0.78 & 3,51 & 1,08 & 4.77 & 1.29 & 3.79 & 3,28 & 1,166 & 6.61 & 6.27 & 3.54 & & & & & & & \\
\hline \multicolumn{2}{|c|}{ 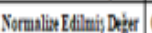 } & 0.06 & & 0.01 & 0.03 & 0.04 & 0.01 & 0.02 & 0.08 & 0.06 & 0.11 & 0.080 & 0.010 & 0.05 & 0.020 & 0.070 & 0.02 & 0.05 & & 0.020 & 0.090 & 0,09 & 0.05 & & & & & & & \\
\hline
\end{tabular}

Şekil 4. Kalite evi.

Yem işletmesi için oluşturulan kalite evinde 22 müşteri beklentisi için 22 teknik karakteristik belirlenmiştir. Müşteri beklentisi kısmı yani "ne”'ler için en önemli ölçütler “Teslimatın Zamanında Gerçekleşmesi'”, “Besin, Protein vb. Değerlerin Yüksek Olması", "'Bütçeye Uygun Fiyat'” olarak sonuçlanmıştır. Bu ölçütlere karşılık "nasıl’lar yani teknik karakteristikler olarak en yüksek önem seviyesine sahip ölçüler ise "Ödeme Şekli Fiyat İndirimi”, “Araç Filosunu Artırmak”, "Dağıtım Ağının Sistematikleştirilmesi", ve "Fiyat Standardizasyonu" olarak sonuçlanmıştır.

Yem firmasının en çok dikkat etmesi gereken teknik karakteristik teslimatın zamanında gerçekleşmesi olmalıdır. Müşteri memnuniyeti sağlaması açısından önemli ölçütler arasında çözüm oluşturmaktadır. Dikkate alınması gereken teknik ölçüt olarak ise araç filosunu artırmak ve ürün takip sistemi oluşturmak pozitif ilişkiye sahiptir.

Genel anlamda bakıldığında; teslimatın zamanında gerçekleşmesi, fiyat standardizasyonu oluşturmak ve taşıma esnasında yemin zarar görmemesi gibi ölçütlere çözüm niteliğinde adımlar atılması gerekmektedir. Eğitim programları düzenlenerek teknik yap1 güçlendirilmelidir. Yemin üretim aşamasında karşılaşılan sorunlara anında müdahale edilebilecek kalite kontrol noktaları oluşturularak zaman kaybı ve ürün hasar oranı düşürülmesi beklenmektedir. 
Kullanım kitapçığı hazırlanması, kaliteli ip kullanılması ve web sitesi uygulamalı videolar hazırlanmasi; kullanıcılara ek bilgi (tavsiyeler) sunulmas1, paketin kolay açılması, üretilen yemin her aşamada izlenebilir olması gibi ölçütler için hazırlanmış teknik karakteristiklerdir. Bu isteklerin diğer isteklere nazaran önem seviyesi düşük olduğundan ilk etapta önem seviyesi yüksek beklentilerin karşılanmasında ağırlık verilmesi gerektiği anlaşılmaktadır. Kalite evinin çatı matrisine bakıldığında, yem işletmesinin müşteri beklentilerine karşılık belirlediği teknik karakteristikler yani "nasıl”'ların birbirleriyle ilişki durumu çoğunlukta pozitif olduğu görülmektedir. Bu durum firmanın müşteri isteklerini karşılama konusunda sorun yaşamayacağı anlamına gelmektedir.

\section{Sonuçlar ve tartışma}

Hayvancılığın gelişimi, hayvansal ürün üretiminin artması ve en yüksek düzeyde verim sağlanabilmesi tarım gıda ve karma yem sektörünün geliştirilmesine bağlıdır. Özellikle karma yem üretimine artan gereksinim beraberinde zorlu bir rekabeti getirmiştir. Sektörde yer alan işletmelerin üretimlerinin gerçekleştirmelerinde müşterinin sesini ve gereksinimlerini dikkate alarak süreçlerini buna göre düzenlemeleri bu rekabet ortamında avantaj sağlayıcı bir durum oluşturacaktır.

Müşteri beklentilerinin en iyi düzeyde karşılanabilmesi müşterinin ne istediğinin tanımının iyi yapılmasından geçmektedir. Kalite evi bu aşamada müşteri isteklerini en iyi şekilde tanımlamakta ve bu isteklerin nasıl karşılanması gerektiği konusunda önerilerde bulunmaktadır. Yaşanan zorluklar, talep edilenler ve yapılması gerekenleri büyük çerçevede görmemizi sağlaması açısından çok büyük bir avantaj sunmaktadır. Bu bağlamda yem işletmesinde uygulanan KFG yöntemi ile müşteri beklentilerinin en iyi şekilde tanımlanması için gemba analizleri ile yerinde gözlemler yapılarak müşterinin sesinin en doğru şekilde aktarılması amacı desteklenmiştir. Üretilen ürün ve sunulan hizmetler doğrultusunda ihtiyaçların belirlenmesi için anket yoluyla müşterilere sorular yöneltilmiş ve karşıllaştırma yaptırılmıştır. Hazırlanan AHP formu ile kalite, fiyat, paket ve dağıtım kategorileri başlıkları altında yapılan karşılaştırmalar sayesinde müşterinin sesinin en doğru şekilde aktarılması amaçlanmıştır. Sonuçlar ve beklentiler ayrıca işletmede oluşturulan KFG ekibiyle yapılan odak çalışması ile değerlendirilip en doğru teknik karakteristikler bulunmaya çalışılmıştır. Ayrıca, ek olarak 5'li skalada rekabet analizi yapılmış, rakip firmanın beklentilere karşı durumu değerlendirilmiştir. Bu şekilde firmanın beklentileri karşılama konusunda rakip firmaya göre karşılaştırılması da sağlanmıştır.

Yapılan analiz ve değerlendirmeler sonucunda ana kriterlerden kalitenin 0.52 değeriyle öncelikli yüksek önem puanına sahip olduğu, sonrasında fiyatın 0.36 değeriyle yüksek öneme sahip olduğu görülmektedir. Yemin besin içeriklerinin kalitesinin artırılması hayvansal verimin artmasını da beraberinde getirecektir. Müşteri isteklerinin ikili karşılaştırmalar sonucu elde edilen değerlerine göre en çok önem seviyesine sahip gereksinim 0.55 değeri ile teslimatın zamanında gerçekleşmesidir. Teslimatın zamanında gerçekleşmemesi hayvanın günlük alması gereken besin değerini karşılayamamasına ve verimin düşmesine sebebiyet vermektedir. Teslimatın zamanında gerçekleştirilmesi adına çözüm niteliğinde adımlar atılması gerekmektedir. Firmanın piyasada ürün çeşitliliği, ikame ürün ve ürün alternatifi bakımından çok fazla rakibi bulunmaktadır. Bu aşamada firmanın belirlemiş olduğu hedefler korunmalı ve bunun yanı sıra müşteri isteklerinden, 
ödeme kolaylığı sağlanması, ekolojik paket kullanılması ve üretilen yemin her aşamada izlenebilir olmasına ilişkin belirlenmiş olan hedefler artırılmalıdır.

İşletmenin müşteri isteklerine karşılık belirlediği teknik karakteristiklerin birbirleriyle arasındaki ilişki durumunun çoğunlukla pozitif olduğu görülmektedir. $\mathrm{Bu}$ durum işletmenin müşteri beklentilerini karşılaması konusunda herhangi bir sorun ile karşılaşmayacağını göstermekle birlikte rakip firmalara göre avantajını da ortaya koymaktadır. Teknik karakteristikleri gerçekleştirebilme olanağı yüksek olan yem işletmesi teknik gereksinimleri uygulamada rakip firmalarla çok yakın değerlerde durmaktadır. Rakip firmalarla üstünlük elde edebilme ve devamında sürdürebilirliği sağlamak adına var olan durumunu kıyaslama ve değerlendirme yoluna gitmelidir.

Elleuch vd. [17]'nin çalışma sonuçlarına göre ithalata bağımlılığın, otomat üreticisine bağımlılı̆̆ın, işgücü huzursuzluğunun, üretim planlamasının bilgisayarsız yapılmasının, kantarın uzaklığının ve tıkanıklığının ve yetersiz endüstriyel bakımın tarımsal gıda şirketi ALCO'nun üretim tedarik zincirinin en zayıflık faktörleri olduğu görülmüştür. Elde edilen sonuçlar birlikte değerlendirildiğinde sektör için tedarik zinciri ve teslimatın zamanında yetiştirilmesi büyük önem kazanmaktadır. Yöneticilerin müşteri gereksinimlerini değerlendirmelerinde kalite fonksiyonu göçerimi yönteminin sunduğu bu sonuçları dikkate almaları uzun dönem karlılıklarını artıracaktır.

Sonuç olarak gerçekleştirilen bu çalışma 1şı̆̆ında yem işletmesinin geliştirilmesi gereken durumları belirlenmiştir. Kullanılan yöntem ile yem işletmesinin müşterileri ve müşteri gereksinimleri odak noktası kabul edilip, işletmenin kaynaklarını en doğru ve verimli bir şeklide nasıl kullanması gerektiğgi belirtilmeye çalışılmış bununla birlikte rakiplerine karşı avantaj ve üstünlük kazanma konusunda kılavuzluk edilmiştir. Ayrıca, bu uygulama gelecek çalışmalarda KFG yönteminin farklı nitelikteki tarım-gıda işletmeleri için kullanılabilirliği için de örnek oluşturmaktadır. Gelecek çalışmalarda ilgili sektör ya da farklı sektörler için farklı bakış açıları da kullanılarak müşterilerin gereksinimlerinin farklı yönleri de değerlendirilebilir.

\section{Kaynaklar}

[1] Şenköylü N., Türkiye'de ve Dünyada yem sektörüne genel bakış, beklentiler, Türkiye Ziraat Mühendisliği VIII. Teknik Kongresi, Ankara, (2015).

[2] Denli, M., Demirel, R. ve Sessiz, A., Diyarbakır ili karma yem endüstrisinin durumu, Türk Tarım-Gıda Bilim ve Teknoloji Dergisi, 3, 9, 701-706, (2015).

[3] ZMO, Ziraat Mühendisleri Odas1, Hayvancilık Raporu, http://www.zmo.org.tr/genel/bizden_detay.php?kod=29946\&tipi=17\&sube=0, (2018). (Erişim: 10.09.2019)

[4] Abatay, G., Müşteri beklentilerinin karşılanmasına yönelik kalite fonksiyonu göçerimi uygulaması, yüksek lisans tezi, Balıkesir Üniversitesi, Sosyal Bilimler Enstitüsü, İşletme Anabilim Dalı, Balıkesir, 91, (2019).

[5] Bayraktar, F., Yem sektörü, Türkiye Kalkınma Bankası A. Ş. Sektörel araştırmalar, Sa/99-2-8, Araştırma Müdürlüğü, Ankara, TKB Matbaası, 58, (1999).

[6] Türkiye Yem Sanayicileri Birliği Karma Yem Sanayii Raporu, Türkiye Yem Sanayicileri Birliği, Ankara, Poyraz Ofset Matbaacilık http://www.setbir.org.tr/wpcontent/uploads/t\%c3\%9crk\%c4\%b0yemb\%c4\%b0r\%e2\%80\%93-karmayem-sanayii-raporu-2019.pdf, (2019), (Erişim: 09.09.2019) 
[7] GKGM, T.C. Tarım ve Orman Bakanlığı, Gıda ve Kontrol Genel Müdürlüğü, https://www.tarimorman.gov.tr/sgb/Belgeler/SagMenuVeriler/GKGM.pdf, (2019), (Erişim: 09.09.2019)

[8] Buxton, D. R., Quality-Related characteristics of forages as influenced by plant environment and agronomic factors, Animal Feed Science and Technology, 59, 1-3, 37-49, (1996).

[9] Basmacioğlu, H., Karma yem üretiminde pelet kalitesine etki eden etkenler, Hayvansal Üretim, 45,1 23-27, (2004).

[10] Berkum, S. V., Is the Turkish Agri-food sector ready for EU entry. In Conference of 'The Future of Rural Europe in the Global Agri-Food System'Copenhagen, Denmark. (2005, August).

[11] Anıç, H. Ş., Trakya bölgesindeki yem fabrikalarının hammadde temini ve pazarlama sorunları üzerine bir araştırma, Yüksek Lisans Tezi, Trakya Üniversitesi Fen Bilimleri Enstitüsü, Edirne, 60, (2006).

[12] Meuwissen, M. P., Van Asseldonk, M. A., \& Huirne, R., Liability risks in agri-food supply chains: the case of wet feed (No. 725-2016-49710), (2008).

[13] Şahman, M. A., Karma yemlerin genetik algoritmayla maliyet optimizasyonu, Yüksek Lisans Tezi, Selçuk Üniversitesi, Fen Bilimleri Enstitüsü, Konya, 91, (2008).

[14] Tekerli, N., Ege bölgesi karma yem sanayinin mevcut durumunun incelenmesi ve geliştirilmesi üzerine bir araştırma, Yüksek Lisans Tezi, Namık Kemal Üniversitesi, Fen Bilimleri Enstitüsü, Tekirdağ, 55, (2010).

[15] Csikai, A., Opportunities of integrating supply chain quality management and product development with formulation systems in compound feed manufacturing. Quality Assurance and Safety of Crops \& Foods, 3(2), 82-88. (2011).

[16] Yaşar, Y. ve Durmuş, B., Farksal gelişim algoritması ile karma yem maliyet optimizasyonu, Dumlupınar Üniversitesi Fen Bilimleri Enstitüsü Dergisi, 33, 33-44, (2014).

[17] Elleuch, H., Dafaoui, E., El Mhamedi, A., \& Chabchoub, H. (2016). A quality function deployment approach for production resilience improvement in supply chain: case of agrifood industry. IFAC-PapersOnLine, 49(31), 125-130.

[18] Gülsün, B., ve Miç P., Rasyon hazırlamada temel yem miktarlarının ekonomik olarak belirlenmesi için çok amaçlı programlama yaklaşımı, Ömer Halisdemir Üniversitesi Mühendislik Bilimleri Dergisi, 7, 2,2 634-648, (2018).

[19] Akao, Y. ve Mazur, G. H., The leading edge in QFD: past, present and future, International Journal of Quality and Reliability Management, 20 ,1, 20-35, (2003).

[20] Akao, Y., QFD: Past, present, and future, In International Symposium on QFD, Linköping, 97, 2 1-12, (1997).

[21] Kahraman, C., Ertay, T. ve Büyüközkan, G., A fuzzy optimization model for QFD planning process using analytic network approach, European Journal of Operational Research, 171, 2, 390-411, (2006).

[22] Erdil, N. O. ve Arani, O. M., Quality function deployment: more than a design tool. International Journal of Quality and Service Sciences. 11, 2, 142-166, (2019).

[23] Yildiz, M. S. ve Baran, Z., Kalite fonksiyon göçerimi ve homojenize yoğurt üretiminde uygulaması, Ege Akademik Bakış, 11, 1, 59-72, (2011).

[24] Ozdemir, Y., Alcan, P., Basligil, H. ve Cakrak, D., A hybrid QFD-AHP methodology and an application for heating systems in Turkey, An International Journal of Optimization and Control: Theories \& Applications (IJOCTA), 8, 1, 117-126, (2018). 
[25] Aktepe, A., Ersöz, S., Hayyaoğlu, A. N. ve Şakar, B. B., Kalite fonksiyon yayılımı yaklaşımı ile özel bir hastanede hizmet kalitesi iyileştirme üzerine bir uygulama, Uluslararası Mühendislik Araştırma ve Geliştirme Dergisi, 10, 2, 245-251, (2018).

[26] Dai, J. ve Blackhurst, J., A four-phase AHP-QFD approach for supplier assessment: a sustainability perspective, International Journal of Production Research, 50, 19, 5474-5490, (2012).

[27] Franceschini, F., Advanced Quality Function Deployment, USA, CRC Press LLC 208, (2002).

[28] Yenginol, F., Neden kalite fonksiyon göçerimi?, Dokuz Eylül Üniversitesi İşletme Fakültesi Dergisi, 9, 1, 7-15, (2008).

[29] Kurt, H. S. ve Yenilmez, G., Kalite fonksiyon yayılımı: alışveriş merkezleri üzerine bir uygulama, Organizasyon ve Yönetim Bilimleri Dergisi, 9, 1,14-29, (2017).

[30] Güllü, E., ve Ulcay, Y., Kalite fonksiyonu yayılımı ve bir uygulama, Uludağ Üniversitesi Mühendislik-Mimarlık Fakültesi Dergisi, 7, 1, 70-92, (2002).

[31] Saaty, T. L., How to make a decision: the analytic hierarchy process, European Journal of Operational Research, 48, 1: 9-26, (1990).

[32] Dong, Y., Zhang, G., Hong, W. C., and Xu, Y., Consensus models for AHP group decision making under row geometric mean prioritization method. Decision Support Systems, 49(3), 281-289. (2010).

[33] Özcan, E., Danışan, T., \& Eren, T., Hidroelektrik santralların en kritik elektriksel ekipman gruplarının bakım stratejilerinin optimizasyonu için matematiksel bir model önerisi. Pamukkale Üniversitesi Mühendislik Bilimleri Dergisi, 25(4), 498-506. (2019).

[34] Kwong, C. K., \& Bai, H., Determining the importance weights for the customer requirements in QFD using a fuzzy AHP with an extent analysis approach. IIE Transactions, 35(7), 619-626, (2003).

[35] İpekgil, Doğan, Ö. ve Işık, Arıcan, R., İlaç sektöründe kalite fonksiyon göçerimi (KFG) matrisinin oluşturulması, Dokuz Eylül Üniversitesi İşletme Fakültesi Dergisi, 9, 1, 107-123, (2008).

[36] Tunca, M.,Z. ve Bayhan, M., Kalite fonksiyon göçerimi yönteminin tedarikçi seçiminde kullanımı, Pamukkale Üniversitesi Sosyal Bilimler Enstitüsü Dergisi, 11, 53-69, (2012).

[37] Gürsakal, N., Altı Sigma Müşteri Odaklı Yönetim, (2. Baskı), Nobel Yayınları, Ankara, 265, (2005).

[38] Gergin, Z., Akbaş, M., Yurt, M. F. ve Aktüre, A. Ö., Kalite fonksiyonu göçerimi yöntemiyle müşterinin marka algısının arttırılması: taşınabilir şarj cihazları üreten bir firmada uygulama, Beykent Üniversitesi Fen ve Mühendislik Bilimleri Dergisi, 11, 1, 111-136, (2018).

[39] Yazdani, M., Kahraman, C., Zarate, P. ve Onar, S. C., A fuzzy multi attribute decision framework with integration of QFD and grey relational analysis, Expert Systems with Applications, 115, 474-485, (2019).

[40] Koç, E., Evaluation of the students' expectations for an educational institution using quality function deployment method, International Journal of Economics, Commerce and Management, 3, 2348, 0386, (2015).

[41] Uğur, N., Bir üçüncü parti lojistik şirketinde kalite fonksiyonu yayılımı uygulaması, Yüksek Lisans Tezi, İstanbul Teknik Üniversitesi, Fen Bilimleri Enstitüsü, İstanbul, 252, (2007).

[42] Şimşek, M., Toplam Kalite Yönetimi, 4. bs. Alfa Yayınları, İstanbul, 135, (2004). 


\section{EK 1. AHP Karşılaștırma Formu}

\begin{tabular}{|c|c|c|c|c|c|c|c|c|c|c|c|c|c|c|c|c|c|}
\hline & & & & $a K$ & rite & rie & ring & $\mathrm{A}$ & $\operatorname{sirl}$ & Kla & ind & inril & ma & & & & \\
\hline Kalite & \begin{tabular}{|l|}
9 \\
\end{tabular} & 8 & 7 & 6 & 5 & 4. & 3 & 2 & 1 & 2 & 3 & 4 & 5 & 6 & 7 & 8 & \begin{tabular}{l|l|}
9 & Fiyat \\
\end{tabular} \\
\hline Kalite & \begin{tabular}{|l|}
9 \\
\end{tabular} & 8 & 7 & 6 & 5 & 4. & 3 & 2 & 1 & 2 & 3 & 4 & 5 & 6 & 7 & & 9 Paket/ Ambalaj \\
\hline Kalite & 9 & 8 & 7 & 6 & 5 & 4. & 3 & 2 & 1 & 2 & 3 & 4 & 5 & 6 & 7 & 8 & \begin{tabular}{l|l}
9 & Dağıtım \\
\end{tabular} \\
\hline Fiyat & 9 & 8 & 7 & 6 & 5 & 4. & 3 & 2 & 1 & 2 & 3 & 4 & 5 & 6 & 7 & 8 & 9 Paket/ Ambalaj \\
\hline Fiyat & 9 & 8 & 7 & 6 & 5 & 4. & 3 & 2 & 1 & 2 & 3 & 4 & 5 & 6 & 7 & 8 & \begin{tabular}{l|l}
9 & Dağıtım \\
\end{tabular} \\
\hline Paket/ Ambalaj & 9 & 8 & 7 & 6 & 5 & 4. & 3 & 2 & 1 & 2 & 3 & 4 & 5 & 6 & 7 & 8 & \begin{tabular}{l|l}
9 & Dağıtım \\
\end{tabular} \\
\hline
\end{tabular}

Kalite

\begin{tabular}{|c|c|c|c|c|c|c|c|c|c|c|c|c|c|c|c|}
\hline $\begin{array}{l}\text { Besin, Protein vb. Değerlerin } \\
\text { Yüksek Olması }\end{array}$ & 9 & & 7 & \begin{tabular}{l|l}
6 & 5
\end{tabular} & 4 & 3 & \begin{tabular}{l|l|l|}
2 & 1
\end{tabular} & 2 & 3 & 45 & & $5 \mid 7$ & 8 & & $\begin{array}{l}\text { Kullanma Talimatlarının } \\
\text { (Ölçeklerinin) Belirtilmesi }\end{array}$ \\
\hline $\begin{array}{l}\text { Besin, Protein vb. Değerlerin } \\
\text { Yüksek Olması }\end{array}$ & 9 & 8 & 7 & \begin{tabular}{l|l}
6 & 5
\end{tabular} & 4 & 3 & \begin{tabular}{l|l}
2 & 1
\end{tabular} & 2 & 3 & 45 & & \begin{tabular}{l|l|}
6 & 7
\end{tabular} & 8 & 9 & $\begin{array}{l}\text { Kullanıcılara Ek Bilgi (Tavsiyeler) } \\
\text { Sunması (İnternet vb.) }\end{array}$ \\
\hline $\begin{array}{l}\text { Besin, Protein vb. Değerlerin } \\
\text { Yüksek Olmas1 }\end{array}$ & 9 & 8 & 7 & \begin{tabular}{l|l}
6 & 5
\end{tabular} & 4 & 3 & \begin{tabular}{l|l|l|}
2 & 1
\end{tabular} & 2 & 3 & 45 & & \begin{tabular}{l|l|}
6 & 7
\end{tabular} & 8 & 9 & $\begin{array}{l}\text { Yeterli Teknik Düzey ve Elemana } \\
\text { Sahip Olması }\end{array}$ \\
\hline $\begin{array}{l}\text { Besin, Protein vb. Değerlerin } \\
\text { Yüksek Olmas1 }\end{array}$ & 9 & & 7 & & 4 & 3 & \begin{tabular}{l|l|}
2 & 1
\end{tabular} & 2 & 3 & 45 & 56 & \begin{tabular}{l|l|}
6 & 7
\end{tabular} & 8 & 9 & $\begin{array}{l}\text { Üretimde Yabancı Maddelerin } \\
\text { Önlenmesi (Dikiş iğnesi, İp vb.) }\end{array}$ \\
\hline $\begin{array}{l}\text { Besin, Protein vb. Değerlerin } \\
\text { Yüksek Olması }\end{array}$ & 9 & 8 & 7 & & 4 & 3 & \begin{tabular}{l|l|l|}
2 & 1
\end{tabular} & 2 & 3 & 45 & 56 & \begin{tabular}{ll|}
6 & 7
\end{tabular} & 8 & 9 & $\begin{array}{l}\text { Üretilen Yemin Her Aşamada } \\
\text { İzlenebilir Olması }\end{array}$ \\
\hline $\begin{array}{l}\text { Besin, Protein vb. Değerlerin } \\
\text { Yüksek Olması }\end{array}$ & 9 & 8 & 7 & \begin{tabular}{l|l}
6 & 5
\end{tabular} & 4 & 3 & \begin{tabular}{l|l}
2 & 1
\end{tabular} & 2 & 3 & 45 & & \begin{tabular}{l|l|}
6 & 7
\end{tabular} & 8 & 9 & $\begin{array}{l}\text { HACCP Şartlarına Uygun Üretim } \\
\text { Yapılması }\end{array}$ \\
\hline $\begin{array}{l}\text { Kullanma Talimatlarının } \\
\text { (Ölçeklerinin) Belirtilmesi }\end{array}$ & 9 & 8 & 7 & \begin{tabular}{l|l}
6 & 5
\end{tabular} & 4 & 3 & \begin{tabular}{l|l|l|}
2 & 1
\end{tabular} & 2 & 3 & 45 & 56 & \begin{tabular}{l|l|}
6 & 7
\end{tabular} & 8 & 9 & $\begin{array}{l}\text { Kullanıcılara Ek Bilgi (Tavsiyeler) } \\
\text { Sunması (İnternet vb.) }\end{array}$ \\
\hline $\begin{array}{l}\text { Kullanma Talimatlarının } \\
\text { (Ölçeklerinin) Belirtilmesi }\end{array}$ & 9 & 8 & 76 & \begin{tabular}{l|l}
6 & 5
\end{tabular} & 4 & 3 & \begin{tabular}{l|l|l|}
2 & 1
\end{tabular} & 2 & 3 & 45 & & \begin{tabular}{l|l|}
6 & 7
\end{tabular} & 8 & 9 & $\begin{array}{l}\text { Yeterli Teknik Düzey ve Elemana } \\
\text { Sahip Olması }\end{array}$ \\
\hline $\begin{array}{l}\text { Kullanma Talimatlarının } \\
\text { (Ölçeklerinin) Belirtilmesi }\end{array}$ & 9 & 8 & 7 & & 4 & 3 & \begin{tabular}{l|l}
2 & 1
\end{tabular} & 2 & 3 & 45 & & \begin{tabular}{ll|}
6 & 7
\end{tabular} & 8 & 9 & $\begin{array}{l}\text { Üretimde Yabancı Maddelerin } \\
\text { Önlenmesi (Dikiş iğnesi, İp vb.) }\end{array}$ \\
\hline $\begin{array}{l}\text { Kullanma Talimatlarının } \\
\text { (Ölçeklerinin) Belirtilmesi }\end{array}$ & 9 & 8 & 7 & \begin{tabular}{l|l}
6 & 5
\end{tabular} & 4 & 3 & \begin{tabular}{l|l|l|}
2 & 1
\end{tabular} & 2 & 3 & 45 & 56 & \begin{tabular}{l|l|}
6 & 7
\end{tabular} & 8 & 9 & $\begin{array}{l}\text { Üretilen Yemin Her Aşamada } \\
\text { İzlenebilir Olması }\end{array}$ \\
\hline $\begin{array}{l}\text { Kullanma Talimatlarının } \\
\text { (Ölçeklerinin) Belirtilmesi }\end{array}$ & 9 & & 7 & \begin{tabular}{l|l}
6 & 5
\end{tabular} & 54 & 3 & \begin{tabular}{l|l}
2 & 1
\end{tabular} & 2 & 3 & 45 & & \begin{tabular}{l|l|}
6 & 7
\end{tabular} & 8 & 9 & $\begin{array}{l}\text { HACCP Şartlarına Uygun Üretim } \\
\text { Yapılması }\end{array}$ \\
\hline $\begin{array}{l}\text { Kullanıcılara Ek Bilgi (Tavsiyeler) } \\
\text { Sunması (İnternet vb.) }\end{array}$ & 9 & 8 & 7 & & 54 & 3 & \begin{tabular}{l|l|}
2 & 1
\end{tabular} & 2 & 3 & 45 & 56 & \begin{tabular}{ll|}
6 & 7
\end{tabular} & 8 & 9 & $\begin{array}{l}\text { Yeterli Teknik Düzey ve Elemana } \\
\text { Sahip Olmas1 }\end{array}$ \\
\hline $\begin{array}{l}\text { Kullanıcılara Ek Bilgi (Tavsiyeler) } \\
\text { Sunması (İnternet vb.) }\end{array}$ & 9 & 8 & 7 & \begin{tabular}{l|l}
6 & 5
\end{tabular} & 54 & 3 & \begin{tabular}{l|l|l|}
2 & 1
\end{tabular} & 2 & 3 & 45 & 56 & \begin{tabular}{ll|}
6 & 7
\end{tabular} & 8 & 9 & $\begin{array}{l}\text { Üretimde Yabancı Maddelerin } \\
\text { Önlenmesi (Dikiş iğnesi, İp vb.) }\end{array}$ \\
\hline $\begin{array}{l}\text { Kullanıcılara Ek Bilgi (Tavsiyeler) } \\
\text { Sunması (İnternet vb.) }\end{array}$ & 9 & 8 & 7 & & 5 & 3 & \begin{tabular}{l|l}
2 & 1
\end{tabular} & 2 & 3 & 45 & 56 & $5|7|$ & 8 & 9 & $\begin{array}{l}\text { Üretilen Yemin Her Aşamada } \\
\text { İzlenebilir Olması }\end{array}$ \\
\hline $\begin{array}{l}\text { Kullanıcılara Ek Bilgi (Tavsiyeler) } \\
\text { Sunması (İnternet vb.) }\end{array}$ & 9 & 8 & 7 & 6 & 4 & 3 & \begin{tabular}{l|l}
2 & 1
\end{tabular} & 2 & 3 & 45 & 56 & $5 \mid 7$ & 8 & 9 & $\begin{array}{l}\text { HACCP Şartlarına Uygun Üretim } \\
\text { Yapılmas1 }\end{array}$ \\
\hline $\begin{array}{l}\text { Yeterli Teknik Düzey ve Elemana } \\
\text { Sahip Olmas1 }\end{array}$ & 9 & & 7 & & 4 & 32 & \begin{tabular}{l|l}
2 & 1
\end{tabular} & 2 & 3 & 45 & 56 & 57 & 8 & 9 & $\begin{array}{l}\text { Üretimde Yabanc1 Maddelerin } \\
\text { Önlenmesi (Dikiş iğnesi, İp vb.) }\end{array}$ \\
\hline $\begin{array}{l}\text { Yeterli Teknik Düzey ve Elemana } \\
\text { Sahip Olması }\end{array}$ & 9 & 8 & 7 & & 5 & 32 & \begin{tabular}{l|l}
2 & 1
\end{tabular} & 2 & 3 & 45 & 56 & 57 & 8 & 9 & $\begin{array}{l}\text { Üretilen Yemin Her Aşamada } \\
\text { İzlenebilir Olması }\end{array}$ \\
\hline $\begin{array}{l}\text { Yeterli Teknik Düzey ve Elemana } \\
\text { Sahip Olması }\end{array}$ & 9 & 8 & 7 & \begin{tabular}{l|l}
65 \\
\end{tabular} & 54 & 32 & \begin{tabular}{l|l}
2 & 1
\end{tabular} & 2 & 3 & 45 & 56 & $5 \mid 7$ & 8 & 9 & $\begin{array}{l}\text { HACCP Şartlarına Uygun Üretim } \\
\text { Yapılması }\end{array}$ \\
\hline $\begin{array}{l}\text { Üretimde Yabancı Maddelerin } \\
\text { Önlenmesi (Dikiş iğnesi, İp vb.) }\end{array}$ & 9 & 8 & 7 & \begin{tabular}{l|l}
6 & 5
\end{tabular} & 5 & 3 & \begin{tabular}{l|l|l|}
2 & 1
\end{tabular} & 2 & 3 & 45 & 56 & $5 \mid 7$ & 8 & 9 & $\begin{array}{l}\text { Üretilen Yemin Her Aşamada } \\
\text { İzlenebilir Olması }\end{array}$ \\
\hline $\begin{array}{l}\text { Üretimde Yabancı Maddelerin } \\
\text { Önlenmesi (Dikiş iğnesi, İp vb.) }\end{array}$ & 9 & 8 & 7 & \begin{tabular}{l|l}
6 & 5
\end{tabular} & 54 & 3 & \begin{tabular}{l|l|l|}
2 & 1
\end{tabular} & 2 & 3 & 45 & 56 & 57 & 8 & 9 & $\begin{array}{l}\text { HACCP Şartlarına Uygun Üretim } \\
\text { Yapılması }\end{array}$ \\
\hline $\begin{array}{l}\text { Üretilen Yemin Her Aşamada } \\
\text { İzlenebilir Olması }\end{array}$ & 9 & & 7 & & & 32 & $\begin{array}{lll}2 & 1\end{array}$ & 2 & 3 & 45 & 56 & 57 & 8 & 9 & $\begin{array}{l}\text { HACCP Şartlarına Uygun Üretim } \\
\text { Yapılması }\end{array}$ \\
\hline
\end{tabular}

Fiyat

\begin{tabular}{|c|c|c|c|c|c|c|c|c|c|c|c|c|c|c|c|c|}
\hline Bütçeye Uygun Fiyat & \begin{tabular}{|l|}
9 \\
\end{tabular} & 8 & 7 & 6 & 5 & 4 & 3 & \begin{tabular}{|l|l|}
2 & 1 \\
\end{tabular} & 2 & 3 & 4 & 5 & 7 & & 9 & Ödeme Kolaylığ1 Sağlamas1 \\
\hline Bütçeye Uygun Fiyat & 9 & & 7 & 6 & 5 & 4 & & 2 & 2 & 3 & 4 & 5 & 5 & & & $\begin{array}{l}\text { Promosyonlu Fiyat Uygulamas1 } \\
\text { Yapılmas1 }\end{array}$ \\
\hline Bütçeye Uygun Fiyat & 9 & 8 & 7 & 6 & 5 & 4 & 3 & \begin{tabular}{|l|l|}
2 & 1 \\
\end{tabular} & 2 & 3 & 4 & 5 & 57 & & 9 & Opsiyon Tanınmas1 \\
\hline Ödeme Kolaylığı Sağlaması & 9 & 8 & 7 & 6 & 5 & 4 & & 21 & 2 & 3 & 4 & 5 & 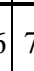 & & 9 & $\begin{array}{l}\text { Promosyonlu Fiyat Uygulamas1 } \\
\text { Yapılmas1 }\end{array}$ \\
\hline Ödeme Kolaylığ1 Sağlaması & \begin{tabular}{|l|}
9 \\
\end{tabular} & 8 & 7 & 6 & 5 & 4 & 3 & $\begin{array}{lll}2 & 1\end{array}$ & 2 & 3 & 4 & 5 & 57 & 0 & 9 & Opsiyon Tanınması \\
\hline $\begin{array}{l}\text { Promosyonlu Fiyat Uygulamas1 } \\
\text { Yap1lmas1 }\end{array}$ & 9 & 8 & 7 & 6 & 5 & & & 21 & 2 & & & 5 & & & & Opsiyon Tanınması \\
\hline
\end{tabular}


Paket/ Ambalaj

\begin{tabular}{|c|c|c|c|c|c|c|c|c|c|c|c|c|c|c|c|c|}
\hline Paketin Kolay Açılması & 9 & 87 & & & & 43 & & & 2 & 3 & 4 & 5 & 67 & 7 & 89 & $\begin{array}{l}\text { Paketin Dayanıklı Olması } \\
\text { (Patlama, Stzdırma Olmaması) }\end{array}$ \\
\hline Paketin Kolay Açılması & 9 & 87 & 76 & 65 & \begin{tabular}{l|l}
5 & 4
\end{tabular} & 43 & & 1 & 2 & 3 & 4 & 5 & 67 & 7 & 89 & Ekolojik Paket Kullanılması \\
\hline Paketin Kolay Açılması & 9 & 87 & 76 & 65 & $5 \mid 4$ & 43 & & 1 & 2 & 3 & 4 & 5 & 6 & 7 & 89 & $\begin{array}{l}\text { Her Pakette Ürün Bilgilerini } \\
\text { İçeren Etiket Bulunması }\end{array}$ \\
\hline Paketin Kolay Açılması & 9 & 87 & 76 & 65 & $5 \mid 4$ & 43 & & 1 & 2 & 3 & 4 & 5 & 67 & 7 & 89 & $\begin{array}{l}\text { Paket Üzerinde İçindeki Yemin } \\
\text { Net Değerinin Belirtilmesi }\end{array}$ \\
\hline Paketin Kolay Açılması & 9 & 87 & 76 & 65 & $5 \mid 4$ & 43 & & 1 & 2 & 3 & 4 & 5 & 6 & 7 & 89 & $\begin{array}{l}\text { Ambalajın Yemin Yoğunluğuna } \\
\text { Göre Yapılması }\end{array}$ \\
\hline Paketin Kolay Açılması & 9 & 87 & 76 & 65 & $5 \mid 4$ & 43 & & 1 & 2 & 3 & 4 & 5 & 67 & 7 & 89 & \begin{tabular}{|l|} 
Paketlerde Boya Baskı ve \\
Ebatların Standartlara Uygun \\
Olması
\end{tabular} \\
\hline $\begin{array}{l}\text { Paketin Dayanıklı Olması } \\
\text { (Patlama, Stzdırma Olmaması) }\end{array}$ & 9 & 87 & 76 & & $5 \mid 4$ & 43 & & 21 & 2 & 3 & 4 & 5 & 67 & 7 & 89 & Ekolojik Paket Kullanılması \\
\hline $\begin{array}{l}\text { Paketin Dayanıklı Olması } \\
\text { (Patlama, Stzdırma Olmaması) }\end{array}$ & 9 & 87 & 76 & 65 & $5 \mid 4$ & 43 & & 21 & 2 & 3 & 4 & 5 & 6 & 7 & 89 & $\begin{array}{l}\text { Her Pakette Ürün Bilgilerini } \\
\text { İçeren Etiket Bulunması }\end{array}$ \\
\hline $\begin{array}{l}\text { Paketin Dayanıkı Olması } \\
\text { (Patlama, Sizdırma Olmaması) }\end{array}$ & 9 & 87 & 76 & 65 & $5 \mid 4$ & 43 & & 1 & 2 & 3 & 4 & 5 & 67 & 7 & 89 & $\begin{array}{l}\text { Paket Üzerinde İçindeki Yemin } \\
\text { Net Değerinin Belirtilmesi }\end{array}$ \\
\hline $\begin{array}{l}\text { Paketin Dayanıkı Olması } \\
\text { (Patlama, Sizdırma Olmaması) }\end{array}$ & 9 & 87 & 76 & 65 & $5 \mid 4$ & 43 & & 1 & 2 & 3 & 4 & 5 & \begin{tabular}{l|l}
6 & 7
\end{tabular} & 7 & 89 & $\begin{array}{l}\text { Ambalajın Yemin Yoğunluğuna } \\
\text { Göre Yapılması }\end{array}$ \\
\hline $\begin{array}{l}\text { Paketin Dayanıkı Olması } \\
\text { (Patlama, Sızdırma Olmaması) }\end{array}$ & 9 & 87 & 76 & $\begin{array}{l}6 \\
5\end{array}$ & \begin{tabular}{l|l}
5 & 4
\end{tabular} & 43 & & 1 & 2 & 3 & 4 & 5 & 67 & 7 & 89 & $\begin{array}{l}\text { Paketlerde Boya Bask1 ve } \\
\text { Ebatların Standartlara Uygun } \\
\text { Olmas1 }\end{array}$ \\
\hline Ekolojik Paket Kullanılması & 9 & 87 & 76 & 65 & $5 \mid 4$ & 43 & & 1 & 2 & 3 & 4 & 5 & 67 & 7 & 89 & $\begin{array}{l}\text { Her Pakette Ürün Bilgilerini } \\
\text { İçeren Etiket Bulunması }\end{array}$ \\
\hline Ekolojik Paket Kullanılması & 9 & 87 & 76 & 65 & $5 \mid 4$ & 43 & & 1 & 2 & 3 & 4 & 5 & 6 & 7 & 89 & $\begin{array}{l}\text { Paket Üzerinde İçindeki Yemin } \\
\text { Net Değerinin Belirtilmesi }\end{array}$ \\
\hline Ekolojik Paket Kullanılması & 9 & 87 & 76 & 65 & $5 \mid 4$ & 43 & & 1 & 2 & 3 & 4 & 5 & 67 & 7 & 89 & $\begin{array}{l}\text { Ambalajın Yemin Yoğunluğuna } \\
\text { Göre Yapılması }\end{array}$ \\
\hline Ekolojik Paket Kullanılması & 9 & 87 & 76 & 65 & $\begin{array}{lll}5 & 4\end{array}$ & 43 & & 21 & 2 & 3 & 4 & 5 & \begin{tabular}{l|l}
6 & 7
\end{tabular} & 7 & 89 & $\begin{array}{l}\text { Paketlerde Boya Bask1 ve } \\
\text { Ebatların Standartlara Uygun } \\
\text { Olmas1 }\end{array}$ \\
\hline $\begin{array}{l}\text { Her Pakette Ürün Bilgilerini İçeren } \\
\text { Etiket Bulunmas1 }\end{array}$ & 9 & 87 & 76 & 65 & $5 \mid 4$ & 43 & & 21 & 2 & 3 & 4 & 5 & 6 & 7 & 89 & $\begin{array}{l}\text { Paket Üzerinde İçindeki Yemin } \\
\text { Net Değerinin Belirtilmesi }\end{array}$ \\
\hline $\begin{array}{l}\text { Her Pakette Ürün Bilgilerini İçeren } \\
\text { Etiket Bulunması }\end{array}$ & 9 & 87 & 76 & 65 & 54 & 43 & & 1 & 2 & 3 & 4 & 5 & 6 & 7 & 89 & $\begin{array}{l}\text { Ambalajın Yemin Yoğunluğuna } \\
\text { Göre Yapılması }\end{array}$ \\
\hline $\begin{array}{l}\text { Her Pakette Ürün Bilgilerini İçeren } \\
\text { Etiket Bulunması }\end{array}$ & 9 & 87 & 76 & 65 & \begin{tabular}{l|l}
5 \\
\end{tabular} & 43 & & 1 & 2 & 3 & 4 & 5 & \begin{tabular}{l|l}
6 & 7
\end{tabular} & 7 & 89 & $\begin{array}{l}\text { Paketlerde Boya Bask1 ve } \\
\text { Ebatların Standartlara Uygun } \\
\text { Olması }\end{array}$ \\
\hline $\begin{array}{l}\text { Paket Üzerinde İçindeki Yemin } \\
\text { Net Değerinin Belirtilmesi }\end{array}$ & 9 & 87 & 76 & 65 & 54 & 43 & & 2) 1 & 2 & 3 & 4 & 5 & 6 & 7 & 89 & $\begin{array}{l}\text { Ambalajın Yemin Yoğunluğuna } \\
\text { Göre Yapılması }\end{array}$ \\
\hline $\begin{array}{l}\text { Paket Üzerinde İçindeki Yemin } \\
\text { Net Değerinin Belirtilmesi }\end{array}$ & 9 & 87 & 76 & 65 & \begin{tabular}{l|l|l}
5
\end{tabular} & 43 & & 2 1 & 2 & 3 & 4 & 5 & 6 & 7 & 89 & \begin{tabular}{|l} 
Paketlerde Boya Bask1 ve \\
Ebatların Standartlara Uygun \\
Olmas1
\end{tabular} \\
\hline $\begin{array}{l}\text { Ambalajın Yemin Yoğunluğuna } \\
\text { Göre Yapılması }\end{array}$ & 9 & 87 & 76 & 65 & $5 \mid 4$ & 43 & & 1 & 2 & 3 & 4 & 5 & 6 & 7 & 89 & $\begin{array}{l}\text { Paketlerde Boya Bask1 ve } \\
\text { Ebatların Standartlara Uygun } \\
\text { Olmas1 }\end{array}$ \\
\hline
\end{tabular}

Dağıtım

\begin{tabular}{|c|c|c|c|c|c|c|c|c|c|c|c|c|c|c|c|c|}
\hline Yaygın Dağıtım Ağının Olması & \begin{tabular}{|l|l|}
9 & \\
\end{tabular} & 8 & 7 & \begin{tabular}{l|l}
6 & 5 \\
\end{tabular} & 5 & 43 & & 1 & 2 & \begin{tabular}{l|l}
3 & 2 \\
\end{tabular} & 4 & 56 & 57 & & 9 & Nakliye Kolaylığı Sunması \\
\hline Yaygın Dağıtım Ağının Olması & 9 & & $7 \mid$ & 65 & 5 & 4 & & 1 & 2 & 3 & 4 & 56 & $5 \mid 7$ & 8 & 9 & $\begin{array}{l}\text { Teslimatın Zamanında } \\
\text { Gerçekleşmesi }\end{array}$ \\
\hline Yaygın Dağıtım Ağının Olması & 9 & 8 & 7 & 65 & 5 & 43 & $\begin{array}{l}3 \\
2\end{array}$ & 1 & 2 & 3 & 4 & 56 & 57 & 8 & 9 & $\begin{array}{l}\text { Dağıtımda Yemin Ufalanmasının/ } \\
\text { Ezilmesinin Önlenmesi }\end{array}$ \\
\hline Nakliye Kolaylığı Sunması & 9 & 8 & 7 & 65 & 5 & 43 & ? & 1 & 2 & $3 \mid$ & 4 & 56 & 5 & 8 & 9 & $\begin{array}{l}\text { Teslimatın Zamanında } \\
\text { Gerçekleşmesi }\end{array}$ \\
\hline Nakliye Kolaylığı Sunması & 9 & 8 & 7 & 65 & 5 & 4 & 3 & 1 & 2 & 3 & 4 & 56 & 57 & 8 & 9 & $\begin{array}{l}\text { Dağıtımda Yemin Ufalanmasının/ } \\
\text { Ezilmesinin Önlenmesi }\end{array}$ \\
\hline $\begin{array}{l}\text { Teslimatın Zamanında } \\
\text { Gerçekleşmesi }\end{array}$ & 9 & 8 & 7 & 6 & 5 & 4 & 2 & 1 & 2 & 3 & 4 & 56 & 5 & & & $\begin{array}{l}\text { Dağıtımda Yemin Ufalanmasının/ } \\
\text { Ezilmesinin Önlenmesi }\end{array}$ \\
\hline
\end{tabular}




\section{EK 2. Rakip Analiz Formu}

Aşağıdaki kriterlere göre ismi yazılı firmaları 1' den 5' e kadar numara vererek değerlendirir misiniz?

1. Çok Kötü

2. Kötü

3. Kismen İyi

4. İyi

5. Çok İyi

\begin{tabular}{|c|c|c|}
\hline \multirow{2}{*}{$\begin{array}{l}\text { Besin, Protein vb. Değerlerin Yüksek } \\
\text { Olması }\end{array}$} & Firma & Rakip Firma \\
\hline & & \\
\hline $\begin{array}{l}\text { Kullanma Talimatlarının (Ölçeklerinin) } \\
\text { Belirtilmesi }\end{array}$ & & \\
\hline $\begin{array}{l}\text { Kullanıcılara Ek Bilgi (Tavsiyeler) } \\
\text { Sunması (İnternet vb.) }\end{array}$ & & \\
\hline $\begin{array}{l}\text { Yeterli Teknik Düzey ve Elemana Sahip } \\
\text { Olmas1 }\end{array}$ & & \\
\hline $\begin{array}{l}\text { Üretimde Yabanc1 Maddelerin } \\
\text { Önlenmesi (Dikiş iğnesi, İp vb.) }\end{array}$ & & \\
\hline $\begin{array}{l}\text { Üretilen Yemin Her Aşamada İzlenebilir } \\
\text { Olmas1 }\end{array}$ & & \\
\hline $\begin{array}{l}\text { HACCP Şartlarına Uygun Üretim } \\
\text { Yapılması }\end{array}$ & & \\
\hline Bütçeye Uygun Fiyat & & \\
\hline Ödeme Kolaylığı Sağlaması & & \\
\hline $\begin{array}{l}\text { Promosyonlu Fiyat Uygulamas1 } \\
\text { Yap1lmas1 }\end{array}$ & & \\
\hline Opsiyon Tanınması & & \\
\hline Paketin Kolay Açılması & & \\
\hline $\begin{array}{l}\text { Paketin Dayanıklı Olması (Patlama, } \\
\text { Sizdırma Olmaması) }\end{array}$ & & \\
\hline Ekolojik Paket Kullanılması & & \\
\hline $\begin{array}{l}\text { Her Pakette Ürün Bilgilerini İçeren } \\
\text { Etiket Bulunmas1 }\end{array}$ & & \\
\hline $\begin{array}{l}\text { Paket Üzerinde İçindeki Yemin Net } \\
\text { Değerinin Belirtilmesi }\end{array}$ & & \\
\hline $\begin{array}{l}\text { Ambalajin Yemin Yoğunluğuna Göre } \\
\text { Yapılması }\end{array}$ & & \\
\hline $\begin{array}{l}\text { Paketlerde Boya Bask1 ve Ebatların } \\
\text { Standartlara Uygun Olmas1 }\end{array}$ & & \\
\hline Yaygın Dağıtım Ağının Olması & & \\
\hline Nakliye Kolaylığı Sunması & & \\
\hline Teslimatın Zamanında Gerçekleşmesi & & \\
\hline $\begin{array}{l}\text { Dağıtımda Yemin Ufalanmasının/ } \\
\text { Ezilmesinin Önlenmesi }\end{array}$ & & \\
\hline
\end{tabular}

